\title{
ZACHOWANE EGZEMPLARZE Z BIBLIOTEK POLSKICH WAZÓW
}

Poszukiwania biblioteczne zmierzające do ustalenia liczby zachowanych do dziś książek należących do Zygmunta II i jego synów, które przeprowadzałam w latach 1984-1987, doprowadziły do następujących wyników: w sumie odnalazłam 154 tytuły ( 3 dublety) w 149 woluminach, w tym 5 rękopisów. Wśród zachowanych egzemplarzy znajdujemy 36 poloników, w tym 13 utworów dedykowanych. Najwięcej egzemplarzy Wazów znajduje się w bibliotekach szwedzkich (103 tytuły) i polskich (48 tytułów) ${ }^{1}$.

Nie wszystkie egzemplarze mogłam zobaczyć. W bibliotekach zagranicznych udało mi się dotrzeć tylko do książek Wazów znajdujących się dziś w Bibliotece Uniwersyteckiej w Lund, gdzie opisałam 60 tytułów. Z pozostałych bibliotek otrzymałam informacje o proweniencji, odbitki lub przerysy superekslibrisów. Książki odziedziczone przez Zygmunta III po Zygmuncie Auguście, znajdujące się w Uppsali, mogłam opisać dzięki udostępnieniu mi przez Panią Profesor A. Kawecką-Gryczową maszynopisu katalogu wydanego drukiem w $1988 \mathrm{r}^{2}$ Informacje o trzech książkach znajdujących się w Bibliotece Uniwersyteckiej w Wilnie oparłam na pracach E. Laucevičiusa i V. Kisarauskasa ${ }^{3}$.

Zachowane do dziś w bibliotekach polskich egzemplarze przebadałam w Bibliotece Narodowej, Bibliotece Uniwersytetu Warszawskiego, Bibliotece Jagiellońskiej i Bibliotece Kapitulnej w Łowiczu. Z pozostałych bibliotek otrzymałam informacje o proweniencji i fotografie lub przerysowane ołówkiem superekslibrsy ${ }^{4}$. Opisy zachowanych egzemplarzy porównałam z opisami zawartymi w ważniejszych bibliografiach lub drukowanych katalogach, z powołaniem na nie.

Na podstawie zachowanych do dziś egzemplarzy można powiedzieć, że jest to zbiór dzieł $z$ różnych dziedzin wiedzy, w których znajdujemy wiele pięknych wydań ${ }^{5}$. Podobnie jak w innych współczesnych księgozbiorach jest kilka introligatorskich klocków. W jednym woluminie oprawiano najczęściej 2-5 tytułów. Zachowane egzemplarze stawiają Zygmunta III i jego synów w gronie prawdziwych bibliofilów. Dbali oni zarówno o zawartość treściową jak i szatę zewnętrzną swych książek. Oprawy egzemplarzy Wazów oceniane są przez badaczy bardzo wysoko ${ }^{6}$. Zygmunt III był estetą. lubił piękno kształtu i barwy, starał się nadać własnym książkom cechy niepowtarzalności przez wykwintną oprawę. Jego oprawy odznaczają się wysokimi walorami i odzwierciedlają poczucie piękna i zmysł artystyczny. Nie znamy nazwisk introligatorów pracujących dla Zygmunta III, ale możemy przypuszczać, że pracowali oni pod kierunkiem króla, który prawdopodobnie sam projektował niektóre oprawy. Nabytki Zygmunta III były oprawiane w skórę (sza- 
gryn, marokin, safian) czerwoną, czenwono-brązową, brazową i pergamin koloru kości słoniowej. Oprawy różnią się złoceniami i rozmaitością stosowanych ornamentów. Wspólną cechą wszystkich opraw Zygmunta III jest superekslibris herbowy, Snopek Wazów. Herb Wazów znajduje się najczęściej w sercu polowym małej tarczy z herbami Szwecji i Gotlandii, która jest umieszczana na większej czteropolowej tarczy z herbami Polski i Litwy. Superekslibris umieszczony jest zawsze na przedniej okładce i nie zawsze na tylnej okładce. Od roku 1601, tj. od otrzymania orderu Złotego Runa, Zygmunt III ozdabiał książki superekslibrisem herbowym okolonym łańcuchem orderu Złotego Runa.

Adam Heymowski wyróżnił pięć odmian opraw książek Zygmunta III wykonanych w Polsce i trzy oryginalne luksusowe oprawy donacyjne wykonane we Włoszech ${ }^{7}$. Superekslibrisy wykonane w Polsce zmieniały się w miarę uptywu lat następująco:

1. na tarczy koronnej z Orłem Polski umieszczano herb Wazów,

2. na tarczy czteropolowej, ostro zakończonej, z herbami Polski i Litwy umieszczano małą tarczę z herbami Szwecji i Gotlandii, w sercu polowym znajdowal się herb Wazów,

3. tarcza podobna do poprzedniej okolona łańcuchem orderu Złotego Runa,

4. tarcza owalna z herbami Polski, Litwy, Szwecji i Gotlandii; w sercu polowym herb Wazów, z orderem Złotego Runa. Różni się od dwóch poprzednich elementami kompozycyjnymi w stylu barokowym,

5. tarcza owalna w stylu barokowym, bardzo ozdobna, na środku herb Wazów.

W Bibliotece Uniwersyteckiej w Lund zachowała się unikalna oprawa dzieła P. Ribadeneiry posiadająca kolorowy (niebiesko-żółty, biało-czerwony) superekslibris Zygmunta III okolony łańcuchem orderu Złotego Runa. Superekslibris umieszczony jest na przedniej i tylnej okładce, wokół stylizowane obramowania; ozdobny grzbiet, złocone karty.

Na niektórych oprawach książek Zygmunta III, na przedniej okładce, wytłaczano nad superekslibrisem tytuł dzieła a pod superekslibrisem rok oprawy. Część książek, wszystkie zachowane dzieła medyczne, oprawiano w pergamin koloru kości słoniowej i ozdabiano je superekslibrisem na przedniej i tylnej okładce. Oprawy te w porównaniu z oprawami ze skóry są bardzo skromne. Niektóre egzemplarze oprawiane w skórę zaopatrywano w ozdobne klamry i srebrne okucia na narożnikach. Część książek oprawianych w pergamin zawiazzywano skórzanymi rzemykami.

Zygmunt III posiadał także kosztowne oprawy pokryte srebrem, zdobione emalią i złotem. Taką oprawę ma Brewiarz Zygmunta III. Ponadto w posiadaniu Zygmunta III były piękne oprawy książek rodziców, Jana III Wazy i Katarzyny Jagiellonki oraz luksusowe oprawy egzemplarzy z biblioteki Zygmunta Augusta. Książki Zygmunta Augusta były najczęściej podpisywane: „Ex libris Sereniss. Principis", co zostało mylnie zinterpretowane przez niektórych autorów podających, że Zygmunt III zaopatrywał swe książki ekslibrisem ${ }^{8}$. Oprawy włoskie posiadają egzemplarze ofiarowane Zygmuntowi III przez papieży (Annales Ecclesiastici... C. Baroniusa i Revelationes Sanctae Brigittae z 1606 r.).

Oprawy ksiażek Wladysława IV i Jana Kazimierza w dużej mierze przypominają oprawy książek ich ojca. Przypuszczalnie pracowali dla nich introligatorzy 
Zygmunta III lub ich uczniowie, którzy stosowali te same tłoki. Egzemplarze oprawiali w skórę czenwoną lub brązową oraz kremowy i czenwony (purpurowy) pergamin. Centralną ozdobą opraw był superekslibris herbowy umieszczony na przedniej i tylnej okładce. Książki Władysława IV nabyte w okresie, kiedy był królewiczem, opatrzone były napisem: „Ex libris Ser ${ }^{m i}$ Principis Vladislai” lub oprawiano je w pergamin. Na przedniej okładce wytłaczano napis: „VSP” (Dell'introduzzione alla politica... P. Andrea).

Do dziś zachowat się egzemplarz luksusowej oprawy wykonanej dla Wladysława IV jako królewicza (/uris universi conclusio... K.K. Niszczyckiego). Dzieło jest oprawione w purpurowy safian. Na przedniej okładce znajduje się wytłoczony stylizowany duży orzeł w koronie, na którym umieszczono czteropolową tarczę z herbami Szwecji i Gotlandii. W sercu polowym widnieje mała tarcza z herbem Wazów.

Dziś znamy dwie oprawy egzemplarzy Jana Kazimierza (Disputationibus methaphysicae... P. Comitibusa i Opere spirituali... G della Croce). Obie ksiażki oprawione są w pergamin i ozdobione superekslibrisem herbowym z orderem Złotego Runa.

Karol Ferdynand nowe nabytki oprawiał w kremowy pergamin i ozdabiał je superekslibrisem herbowym. Do dziś zachowały się dwie odmiany opraw książek tego królewicza. Jedna z nich posiada wytloczony na tarczy duży Snopek Wazów. Nad kartuszem znajduje się korona, a u dołu order Złotego Runa. Wokół stylizowane ornamenty roślinne. Na górze, na wysokości korony znajdują się wyttoczone inicjały "C.F.P.P." (Examen episcoporum... Venero y Leyva i De bello Cyprio... A.M. Gratianusa). Druga oprawa jest skromniejsza. Na przedniej i tylnej okładce znajduje się wytłoczony bardzo duży Snopek Wazów bez korony i orderu Złotego Runa. Wokół wytłoczone inicjały „C.F.P.P." (Meissnische Land... P. Albinusa, Doctrina temporum... D. Petaviusa i Romanorum antiquitatum... J. Rosina). Na podstawie znanych dziś egzemplarzy Karola Ferdynanda należy przypuszczać że, podobnie jak Zygmunt III, nie posiadał on ekslibrisu, jak to sugerują niektórzy autorzy ${ }^{9}$.

Trudno dziś stwierdzić, w jakim stopniu były wykorzystywane ksiażki Wazów. Prawdopodobnie nie zamykali zazdrośnie swych zbiorów; korzystali z nich sami, czlonkowie ich rodzin, nauczyciele i wychowawcy dzieci królewskich, liczny sztab sekretarzy i urzędników dworskich, bibliotekarze i lekarze królewscy oraz artyści upiększający rezydencje królewskie. O korzystaniu z ksiażek świadczą ślady lektury pozostawione na niektórych egzemplarzach ${ }^{10}$. Są to podkreślenia pewnych fragmentów tekstu i uwagi pisane na marginesach. Być może, że owe ślady lektury były robione ręką późniejszych właścicieli, ale tego dziś nie można jednoznacznie stwierdzić.

\section{Przypisy}

\footnotetext{
${ }^{1}$ Artykul niniejszy jest fragmentem mojej pracy doktorskiej pt. Książka na dworach Wazów w Polsce napisanej pod kierunkiem prof. dr hab. B. Bieńkowskiej, Warszawa 1989 (maszynopis w Oddziale Rękopisów BUW i Instytucie Bibliotekoznawstwa i Informacji Naukowej UW); O poszukiwaniach egzemplarzy Wazów napisałam artykul: Stan badań nad księgozbiorami Wazów, $Z$ badań nad polskimi ksieggozbiorami historycznymi T. 12: 1992 s. 123-136.
}

${ }^{2}$ A. Kawecka-Gryczowa, Biblioteka ostatniego Jagiellona, Wrockaw 1988. 
${ }^{3}$ E. Laucevičius, XV-XVIII a knygu, irišimai Lietuvos bibliotekose, Wilno 1976, s. 117; V. Kisarauskas, Lietuvos knygos zenklai 1518-1918, Wilno 1984, s. 51, 158, 166.

${ }^{4}$ Wiele informacji zawdzięczam uprzejmym odpowiedziom drogą korespondencji, za co składam serdeczne podziękowanie wszystkim osobom i instytucjom, które wykazały zrozumienie dla mojej pracy.

${ }^{5}$ Zawartość treściową oraz stronę typograficzną zachowanych egzemplarzy omówitam wartykule: Próba rekonstrukcji księgozbiorów Wazów, Z badań nad polskimi księgozbiorami historycznymi ( $w$ druku).

${ }^{6}$ O. Walde, Storhetstidens litterära krigsbyten, t. 2, Uppsala 1920, s. 91; A. Heymowski, Reliures armoriées polonaise de l'epoque des Jagellon et des Vasa dans les collection suédoises, W: VIIIe Congréss International des Bibliophiles. Varsovie, 23-29 juillet 1973, Varsovie 1985, s. 150-151.

${ }^{7}$ Tamże, s. 150-151.

${ }^{8}$ Z. Skorupska, Zygmunt III, W: Slownik pracowników książki polskiej. Supl., Warszawa 1986, s. 245.

9 J. Długosz, Waza Karol Ferdynand, op.cit., s. 228.

${ }^{10}$ Spis, poz. 30, 90, 98.

\section{SPIS ZACHOWANYCH DO DZIŚ EGZEMPLARZY Z BIBLIOTEK POLSKICH WAZÓW}

$1^{*}$ Aetius Amidenus, De cognoscendis et curandis morbis sermones sex iam primus in lucem editos... Basel, in officina Frobeniana, $1533,2^{\circ}$

Panzer VI, 294.

Lund BU Fol.Klas.Grek.

Oprawa: Pergamin koloru kości stoniowej. Na przedniej i tylnej okładce złocony superekslibris herbowy Zygmunta III z orderem Złotego Runa.

O.Walde II, 87.

$2^{*}$ Albinus Petrus, Meissnische Land und Berg-Chronica... Dresden, (bey Gim. Bergen), 1589-1590, $2^{\circ}$ Short Catalogue, 17.

Lund BU Hist. Tysk.

Oprawa: Pergamin kremowy. Na przedniej okładce superekslibris Karola Ferdynanda z wytloczonymi inicjałami: „C.F.P.P."

O.Walde II, 83.

$3^{*}$ Andrea Petrus, Dellintroduzzione alla politica... Anversa, appresso Joachimo Tregnefio, $1614,8^{\circ}$ Lund BU Filos.Statsl.

Oprawa: Pergamin kremowy. Na przedniej okładce wytloczone inicjały: "VSP", na tylnej okladce wytloczony herb Wazów.

Prow.: Na k.tyt. ręczny napis: „Ex libris Ser ${ }^{\text {mi }}$ Principis Vladislai".

O.Walde II, 88.

4 Antiphonarium Sacrosanctae Romanae Ecclesiae integrum et completum. Venetiis, apud Pe. Lichtenstein, $1554,2^{\circ}$

Uppsala UB (64.15)

Prow.: 1. Biblioteka Zygmunta Augusta.

2. "Ex libris Serenise. Prin/cip/is” (Zygmunta III).

O.Walde II, 86, A. Kawecka-Gryczowa, poz. 526.

5 Athanasius Magnus, Opera in quattuor tomos distributa, quorum tres sunt a Petro Nannio Alemariano ad Graecorum exemplarium... Basileae, ex off. Episcopiana, 1564, $2^{\circ}$

Graesse 1, 243.

Västerås Stadsbiblioteket

\footnotetext{
Gwiazdka oznaczyłam egzemplarze, które widzialam.
} 
Prow.: 1. „Ex Biblio: Sereniss. Regis Sigismundi”. (Zygmunta III).

2. "Ex Bibliotheca Caroli Frider. Muhrbeck. Carolicor 1776".

$66^{*}$ Athanasius Magnus, Opera quae reperiuntur omnia in duos tomos tributa... (Heidelberg), ex officina Commeliniana, $1601,2^{\circ}$

Graesse 1, 242.

Lund BU Teol.Kyrko-Grek.

Oprawa: Skóra brazowa. Na przedniej okładce wytłoczony złotem superekslibris herbowy Zygmunta III z orderem Złotego Runa.

O.Walde II, 86.

7 Augustinus Aurelius, Operum... T. IV-IX-X. Parisiis, per Dionysius Duvallius, $1586,2^{\circ}$ (2 wol.)

Graesse I, 253.

BGdańska PAN

Oprawa: Skóra czerwona o silnym groszku (marokin) zdobiona złoconymi tloczeniami (motywy roślinne i geometryczne). Na przedniej okladce wytloczony superekslibris herbowy Zygmunta ill. Tylna okladka ozdobiona wytloczonym wizerunkiem Madonny z Dzieciątkiem, nad którą dwa anioły trzymaja koronę.

Prow.: 1. "Ex libris Congregationis Missionis Domus S. Adalberti”.

2. "Andreae Corsz C V".

Z. Nowak, 23-46.

8 Baronius Caesar, Annales Ecclesiastici, T. XI, Romae, ex Typ. Vaticana, 1605, $2^{\circ}$

Estr. 12, 366.

Västerâs Stadsbiblioteket

Oprawa: Skóra czerwona (marokin) zdobiona złoconymi tloczeniami. Na przedniej okladce wyttoczony złotem superekslibris herbowy Zygmunta III.

O.Walde II, 91.

$9^{*}$ Barozzi Giacomo da Vignola M., Le due regole della prospettiva pratica... Roma, per Francesco Zanetti, $1583,2^{\circ}$

BMC 19, 363.

BN XVI.F.3178

(współopr. z: Pomodoro Giovanni, Geometria pratica... poz. 115)

$10^{*}$ Bartholomaeus Angelicus, Liber de proprietatibus re(rum)... Ordinis Minorum. Argentine, (G. Husner), $1505,2^{\circ}$

Short Catalogue, 67.

BUW 28.6.8.11.

Oprawa: Skóra brazzowa z ozdobnymi thoczeniami. Zachowala się tylko przednia okładka.

Prow:: 1. "Ser(enissimi) Principis Caroli Ferdinandi".

2. Biblioteka Zaluskich.

$11^{*}$ Bassianus (Bassiani) Landus Placentini, latrologia. Dialogi duo in quibus de universae artis Medicae... Basileae, ex officina loannis Oporini, 1543, $4^{\circ}$

Short Catalogue, 482.

Lund BU Med.Allm.Rar.Saml.

Oprawa: Pergamin koloru kości słoniowej. Na przedniej i tylnej okładce wytloczony superekslibris Zygmunta III z orderem Zlotego Runa.

O.Walde II, 87.

$12^{*}$ Bayer Johann, Uranometria... Augustae Vindelicorum, excudit Christophorus Mangus, 1603, $2^{\circ}$

Graesse I, 314.

Lund BU Astron.Stellar.

Prow.: 1. "Ex libris Niewiescinski a. 1605".

2. "Ser ${ }^{\text {mi }}$ Principis Ferdinandi".

O.Walde II, 74 .

13 Bellarmino (Bellarminus) Robert, Disputationes... De controversiis Christianae fidei. Ingolstadii, ex officina typographica Davidis Sartorii, $1588,2^{\circ}$ 
Graesse I, 326.

BSem.Duch. Lublin

Oprawa: Skóra czerwona zdobiona zloconymi ornamentami. Na przedniej okładce wytloczony złotem superekslibris herbowy Zygmunta III. Nad superekslibrisem wytoczony napis: „DISPUTATION. BELLARMINI”. Pod superekslibrisem: „TOMUS PRIMUS 1590”.

Prow.: 1. "Conventus Cracouiensis Carmelitani..." (nieczytelnie).

$14^{*}$ Bellici Giovanni Battista, Nova inventione di fabricar fortezze di varie forme... Venetia, appresso Roberto Mietti, $1592,2^{\circ}$

BN XV!.F. 3178

(wspóiopr. z: Pomodoro Giovanni, Geometria pratica... poz. 115).

15 Bembus Matheus, Pastor viligans sive ars regendi animas... Cracoviae, in officina Andreae Petricovii, $1618,4^{\circ}$

Estr. 12, 458-459.

Berlin Staatsbk

Oprawa: Pergamin koloru kości sloniowej. Na przedniej okładce wytloczony superekslibris herbowy Zygmunta III.

Prow:: 1. "Conwent. Posn. Pro."

2. "Inscriptus Catalogo librorum Coll. Posnan. Soc ${ }^{\text {tis }}$ Jesu 1627 ".

"Józef Jan Lewandowski ofiarował ją biskupowi gnieźnieńskiemu Józefowi Cybichowskiemu 1868".

$16^{*}$ Bernardus (Sanctus), Opera omnia. Parisiis, $1602,2^{\circ}$

Lund BU Teol Medelt.

Oprawa: Skóra czerwona (safian). Na przedniej okładce wytloczony zlotem superekslibris herbowy Zygmunta III. Nad superekslibrisem napis: „Divi Bernardi”, pod superekslibrisem: „Opera omnia”. $\mathrm{Na}$ tylnej okładce wytloczony wizerunek Madonny. Na obu okładkach wytloczono w narożnikach wyobrażenia czterech Ewangelistów. Dzieło zamykają dwie ozdobne metalowe klamry.

O.Walde II, 88 .

17 Bertachinus loannes: Tractatus de episcopo... cui non incommoda sunt annexa summaria... Preposito perutili Repertorio... Recuditur Lug(duni) per Ben. Bonnyn, 1533, $8^{\circ}$

|Aur 117.967.

Uppsala BU Bokband 1500-t. Polen 2 adl.a.

Prow.: 1. Biblioteka Zygmunta Augusta.

2. „Ex libris Serenissimi Principis" (Zygmunta III).

O.Walde II, 59; A.Kawecka-Gryczowa, poz. 60.

$18^{*}$ Bertrandus Stephanus, Volumen primum Consiliorum ... Lugduni, exc. Claudius Servanius, 1560, $2^{\circ}$

IAur 121

Lund BU Fol.Jur.

Oprawa: Skóra brązowa. Na przedniej i tylnej okladce wythoczony superekslibris herbowy Zygmunta III z orderem Zlotego Runa.

19 Binius Severinus, Concilia generalia et provincionalia, graeca et latina... T. 1-4. Coloniae Agrippinae, sumptibus Antonii Hierati, apud Joannem Gymnicum et Antonium Hierat, 1606, $2^{\circ}$ (6 wol.)

Graesse II, 244.

Lund BU Kyrkokat.Concil. (Fol.)

Oprawa: Skóra brazowa. Na przedniej i tylnej okładce wytloczony superekslibris herbowy Zygmunta III z orderem Zlotego Runa.

. Walde II, 88; Heymowski, s. 151, 159.

$20^{\circ}$ Boccalini Traiano, Originali fatiche di Traiano Boccalini sopra Cornelio Tacito consecrate al gloriosissimo et potentissimo Vladislao Re di Polonia, et Svetia da Frat'Aurelio Boccalino suo vnico figlivolo. $4^{\circ} \mathrm{rkps}$

BN III 6826

Oprawa: skóra czerwona ze zloconymi ornamentami. Na przedniej i tylnej okladce wytloczony superekslibris Wadystawa IV.

Prow: 1. Adam Kazanowski. 
2. "Adam Tytlewski".

3. Biblioteka Potockich w Wilanowie.

Sigismund Vasa, 125, poz. 210.

21 Bock (Tragus) Hieronymus, Kräuter Buch. Darin Unterscheid, Würckung und Namen der Kreüter, so in Deutschen Landen wachsen... Strassburg, Wend. Rihel, 1546, $2^{\circ}$

IAur 120587.

Uppsala BU Bot. fol.Deskr.allm.

Prow.: 1. Biblioteka Zygmunta Augusta.

2. "Ex lib. Serenis-i Prin-is" (Zygmunta Ili).

O.Walde II, 86; A. Kawecka-Gryczowa, poz. 690.

$22^{*}$ Bosio Giacomo, Dell'istoria della sacra religione... Roma, appresso Guglielmo Faccioto, $1602,2^{\circ}$

Brunet I, 1124.

Lund BU Kyrkohist.Andl. Ord.

Oprawa: Pergamin koloru kości stoniowej. Na przedniej i tylnej okladce zlocony superekslibris herbowy Zygmunta III z orderem Zlotego Runa.

O.Walde 11,88 .

$23^{*}$ Bracelli Jacobus, De bello neapolitano, libri sex... Hagenaae, per Johannem Secerium, $1530,8^{\circ}$

Brunet I, 1196.

Lund BU Hist.lt.

Oprawa: Pergamin koloru kości słoniowej. Na przedniej i tylnej okladce złocony superekslibris herbowy Zygmunta III z orderem Zlotego Runa.

O.Walde 11,88 .

$24^{\circ}$ Brahe Tycho, Epistolarum astronomicarum libri. Norimbergae, apud Levinum Hulsium, $1601,4^{\circ}$ Brunet I, 1191.

Lund BU Astron. Allm.

Oprawa: Pergamin kremowy.

Prow.: 1. „Danieli Casimiri Crucius”.

2. „Ex libris Serenissimi Principis Caroli Ferdinandi".

O.Walde II, 76.

$25^{*}$ Breviarum Romanum, Ex decreto Sacrosanctii Consilii Tridentini restitutum... Antverpiae, ex officina Plantiniana, apud viduam et filios loannis Moreti, $1614,2^{\circ}$

Lund BU Teol.Litur. Rom.Kat.(Fol.)

Oprawa: Skóra brazowa tloczona zloceniami.

Prow.; 1. „Ex libris Seren ${ }^{\text {smi }}$ Principis Caroli Ferdinandi".

O.Waide II, 82.

26 „Brewiarz Zygmunta III", Cristoforo Majorana(?) i Matteo Felice (szkoła neapolitańska), między 1471-1476. Pergamin, rkps

BCzart. sygn. rps. 1211

Oprawa: Deski pokryte czerwonym aksamitem. Przednia okładka ozdobiona plakietkami z emalii przeźroczystej na srebrze. Siena XIV/XV w.

Prow.: 1. Papież Sykstus IV.

2. Zygmunt Ill od r. 1621.

3. Stanisław August Poniatowski.

4. Tadeusz Czacki.

5. Adam Jerzy Czartoryski od r. 1816.

Sztuka dworu Wazów w Polsce, s. 68-69, poz. 124; S. Komornicki, s. 22-23.

$27^{*}$ Brigitta (Sancta), Revelationes Sanctae Brigittae. Lübeck, Bartholomaeus Gothan, 1492, $2^{\circ}$

Brunet I, 1259.

BN Inc. F.1192

Oprawa: Skóra brazowa cielęca tloczona w drobny wzór tworzący bordiurę złcizoną z pasów ornamentu kandelabrowego. Pośrodku pięciopolowa tarcza z herbami Szwecji, Gotlandii i Wazów w kolorach: zlotym, niebieskim, czerwonym i białym. Obok wytloczonymi inicjałami „IR". Oprawa pochodzi z $1568 \mathrm{r}$. 
Prow.: 1. Biblioteka Jana III Wazy. „Ex Bibliotheca loannis Tertii Regis Svaeciae. Inscriptus Catalogo Joan Co: a Tarnow".

2. (Biblioteka Zygmunta III).

3. Biblioteka Tarnowskich w Dzikowie.

Sigismund Vasa, s. 50, poz. 14.

28 Brigitta (Sancta), Revelationes S(anctae) Brigittae. Romae, 1606, $2^{\circ}$

Skokloster

Oprawa: Skóra czerwona (marokin). Oprawa donacyjna, włoska. Pośrodku dwie czteropolowe tarcze typu hiszpańskiego unoszące koronę królewską okolone lańcuchem orderu Złotego Runa. Na tarczy prawej z herbami Polski i Litwy w środku umieszczono herb Wazów. Podobnie na czteropolowej tarczy szwedzkiej z herbami Szwecji i Gotlandii znajduje się herb Wazów. Egzemplarz ofiarowany Zygmuntowi III przez Pawła V.

Prow.: 1. Zygmunt III. Ręcznie pisana dedykacja Zygmunta III dla Karola Ferdynanda.

2. "Ex libris Sereniss. Caroli Ferdinandi Sueciae et Poloniae Principis".

3. "Nils Nilsson Brahe, Elbing maj 1657".

Sigismund Vasa, s. 106, poz. 163; A. Heymowski, s. 151, 159, poz. 15.

$29^{*}$ Brigitta (Sancta), Revelationes S(anc)tae Brigittae... Romae, apud Ludouicum Grignanum, $1628,2^{\circ}$ (2 wol.)

BN XVII.4.2493 I-II

Oprawa: Skóra brązowo-czerwona thoczona w drobny zlocony wzór roślinny tworzący bordiurę, z kartuszem pod koroną. Pośrodku dziewięciopolowa tarcza z herbami Polski, Litwy, Szwecji, Gotlandii i Wazów. Oprawa Zygmunta III.

Prow.: 1. Stanislaw Pstrokoński, kanonik warmiński.

2. dar Jana Tarnowskiego arcybiskupa Iwowskiego.

3. Ekslibris: "Ex Bibliotheca Universitatis Leopoliensis".

Sigismund Vasa, s. 86, poz. 93; Sztuka dworu Wazów w Polsce, 5. 70, poz. 131.

2-gi egz.:

Stockholm KB

Oprawa: Skóra brązowa. Na przedniej okładce wytloczony złotem superekslibris Zygmunta III.

Prow:: 1. „Ex bibliotheca J. Rosenhane 1673”.

O.Walde II, 90.

30 Brożek Jan, Arithmetica integrorum.. Cracoviae, ex typographia Matthiae Andreoviensis, $1620,8^{\circ}$

Estr. 13, 362.

BUW Sd.712.80

Oprawa: Pergamin kremowy. Na przedniej i tylnej okładce wytloczony superekslibris królewicza

Wladyslawa.

Prow.: 1. "Kawaler Nowodworski Tucholskiej Szkole darowal”.

2. "M(agister) Andreas Kucharski".

3. "J Fr. Skinderowicz m(anu) p(ropria)".

4. "M(o)n(aste)rii Vąchocen(sis) Sac(cris) Ord(inis) Cisterc(iensis)".

Marginalia nieliczne. Podkreślenia w tekście.

31 Budaeus Gulielmus (Budé Guillaume), De asse (et partibus eius). Parissis, in aedibus Ascensianis, $1524,2^{\circ}$

Brunet I, 1374

Uppsala UB

Prow.: 1. „Joannis Lasco Poloni et amicorum".

2. "Ex libris Sereniss. Prin:is".

3. "Ex lib. Serenissimi Regis Sigismundi".

O.Walde II, 61-62; Heymowski, s. 161, poz. 38; Lindberg, s. 102.

32 Busbequius (Busbeck) Avgerius Gislenius, Epistolae quattuor. Quarum priores due ante aliquot annos in lucem prodierunt sub nomine Itinerum Constantinopolitani et Amasiani... Francofurti, apud hered. Andreae Wecheli, Claud. Marinum, et Joann. Aubrium, 1595, $8^{\circ}$

BMC 125, 422.

Västerås Stadsbiblioteket 
Prow.: 1. "Ex libr. N. Niewiescinski 1597".

2. „Dan. Casim. Crusii".

3. „Ser ${ }^{\mathrm{mi}}$ Principis Caroli Ferdinandi".

$33^{\circ}$ Busca Gabriello, Della architettura militare... Milano, appresso Girolamo Bordone et Pietro Martire Locarni, $1601,4^{\circ}$

Graesse II, 580.

Lund BU Kriegsv. Ingen.

Oprawa: Pergamin koloru kości słoniowej. Na przedniej okładce wytloczony zlotem superekslibris herbowy Zygmunta III.

O. Walde II, 88 .

$34^{*}$ Bzowski Abraham, Historiae Ecclesiasticae ex illustriss. Caesaris Baronii annalibus... Tomus II... Coloniae Agrippinae, sumptibus Antonium Boetzerium, 1617, $2^{\circ}$

Estr. 13, 494.

Lund BU Kyrkohist. Allm.

Oprawa: Skóra czerwona (safian), Na przedniej i tylnej okładce wytloczony złotem superekslibris Zygmunta III z orderem Zlotego Runa.

O.Walde II, 88; Heymowski, s. 159, poz. 12.

$35^{*}$ Bzowski Abraham, Pontifex Romanus... Ad Sereniss, ... Sigismundi ll Poloniae ... Regem. Coloniae Agrippinae, apud Antonium Boëtzërum, 1619, $2^{\circ}$

Estr. 13, 498.

Lund BU Kyrkohist. Gamm.

Oprawa: Pergamin koloru kości sloniowej. Na przedniej i tylnej okladce wytloczony superekslibris Zygmunta III z orderem Zlotego Runa.

Prow.: 1. „Ex libris Sereniss. mi Poloniae et Sueciae Principis Caroli Ferdinandi”.

O.Walde II, 82.

36 Camerarius Joachim (jun.), Symbolorum et emblematum ex herbis et animalibus Centuriae III... Norimbergae, J. Hotfman, 1590, $4^{\circ}$

Graesse II, 25.

BJ Cim. 5505

Oprawa: Skóra brązowa. Na przedniej i tylnej okładce wytłoczony superekslibris Zygmunta III z orderem Zlotego Runa. Na przedniej okladce wytłoczony skrócony tytuł: "SYMBO EMBLEMA”.

Prow.: 1. „Domus Proff. Cracoviensis ad S. Barbaram Soc. Jesu..." (nieczytelnie).

2. "Grzegorz Zbroja”. (podpis ten powtarza się na innych kartach).

3. "darowat Franciszek Domagalski 24/5 1855".

$37^{*}$ Camerarius Philippe, Operae horarum subcisivarum sive meditationae historicae auctores quam antae editae. Centuria prima. Francofurti, typis Egenolphi Emmeli, impensis Petri Kopfii, $1615,8^{\circ}$ BMC 51, 489.

Lund BU Polygr.

Oprawa: Pergamin koloru kości słoniowej.

Prow.: 1. "Ex libris Ser:mi Caroli Ferdinand. Princ. Pol. et Suec.".

O.Walde II, 82.

$38^{*}$ Canisius Heinrich Engelhardus, Vita Sancte Virginis Mechtildis. (Ingolstadt ?), 1601-1604, $4^{\circ}$

BUW Sd,28.7.14.20

Prow: 1. „Serenissimi Principis Caroli Ferdinandi".

2. na s. 25 pieczęć: „A(ndreas) Z(aluski) E(piscopus) C(racoviensis).

3. nak. 537 verso pieczęć ros. BUW.

39 Chalcondylas Laonicus, De origine et rebus gestis Turcorum libri decem... Basileae, per lo. Oporinum ex offic. Lud. Lucii et Mich. Martini Stellae, 1556, $2^{\circ}$

Uppsala UB 1500-t. Polen Fol. $8^{\circ}$

Prow.: 1. Biblioteka Zygmunta Augusta.

2. "Ex lib. Ser. Prin." (Zygmunta HI)

O.Walde II, 86; A. Kawecka-Gryczowa, poz. 742. 
40 Cilli da Pistoia Allessandro, Historia delle sollevationi notabili seguite in Polonia glanni... 1606. 1607. 1608. Pistoia, Antonio Fortunato, $1627,4^{\circ}$

Estr. 14, 286-287.

Uppsala UB

Prow.: 1. "Da Pistoia Sigism. III".

2. "De la Gardie".

O.Walde II, 64

$41^{\circ}$ Clavius Christophorus, Horologiorum nova descriptio. Romae, apud Aloysum Zannettum, $1599,8^{\circ}$ Brunet II, 92.

Lund BU Astr.Instrum.

Oprawa: Pergamin kremowy.

Prow.: 1. "Ex libris Josephi lusoijlae Finnonis et amicorum eius".

2. "Ex libris Ser ${ }^{\mathrm{mi}}$ Principis Vladislai".

O.Walde II, 64

42 Comitibus Petrus de, Disputationes methaphasicae theologicae exagitate... Monachium, $1658,4^{\circ}$ Wilno VUB ||$-4715$

Oprawa: Pergamin. Na przedniej okładce wytloczony superekslibris herbowy Jana Kazimierza z orderem Zlotego Runa.

Laucevičius, s. 56 , ilustr. 183.

$43^{*}$ Concilium Tridentinum: additis declarationibus cardinalium, ex ultima recognitatione loannis Gallemart: et citationibus loan. Sotealli... et Horatii Lucii... Antverpiae, apud loannem Meursium, 1644, $8^{\circ}$

BN XVII.3.19511

Oprawa: Pergamin kremowy. Na przedniej okladce wytloczony superekslibris Karola Ferdynanda: pośrodku herb Wazów z orderem Złotego Runa. Nad kartuszem korona, obok wytloczone inicjaly: "C.F.P.P."

Prow:: 1. "Ex libris Georgiy Joan. Grunowski” (?)

2. "Domuiti (?) Varsav. S.J.(?) Prow. Polona"

3. „Ex Libris Cap. Lodunerolb.(?) 1692" (zapis niewyraźny, przekreślony).

4. "Ex liberalitate... Centis Dni Doctoris Sethi".

5. „1 a Domino Powöhl 1812".

6. "Ex libris V.C. Moncta 1812".

$44^{*}$ Covarruvias a Leya (Leyra) Diego, Opera omnia ... in duos... tomos... Francofurti, sumptibus Sigismundi Feyerabendt, $1583,2^{\circ}$

BMC 71, 301.

Lund BU (Fol.) Jur.Kanon.

Oprawa: Pergamin biały tloczony złoconymi ornamentami i figurami.

Prow.: 1. "Ex Bibliotheca Ser ${ }^{m i}$ Principis Caroli Ferdinandi".

O.Walde II, 82

45 Croce Giovanni della, Opere Spirituali che conducono l'anima alla perfetta unione con dio. Composte dal. Ven. P.F. ... Roma, Francesco Corbolletti, 1627, $8^{\circ}$

Graesse II, 302.

Klasztor SS Wizytek w Warszawie.

Oprawa: Pergamin bialy. Na przedniej i tylnej okładce wytłoczony superekslibris Jana Kazimierza: dziewięciopolowa tarcza pod koroną z herbami Polski, Litwy, Szwecji, Gotlandii i Wazów okolona lańcuchem orderu Złotego Runa. Godło Zakonu Karmelitów Bosych z napisem: „ZELO ZELATVS VSVM PRODN NEQ EXERCITVNM 3 KE".

Prow.: 1. nak. tyt. autograf Ludwiki Marii: "A La Reine".

Sztuka dworu Wazów w Poisce, s. 101, poz. 269.

$46^{*}$ Crusius Martinus, Annales Svevici sive Chronica... Francofurti, ex officina typographica Nicolai Bassaei, 1595, $2^{\circ}$

Graesse II, 305.

Lund BU (Fol.) Hist. Ty Modet. 
Oprawa: Pergamin kremowy. Na przedniej okładce wytloczony superekslibris Karola Ferdynanda (duży Snopek, bez korony). Wokół wytloczone inicjaly: „C.F.P.P."

O.Walde $11,82$.

$47^{*}$ Cuspinian (Kuspinian) Johann Spiesshaymer, De caesaribus atque impp. Romanis opus insigne... Francofurti, typis Wechelianis, apud Claudium Marnium, et heredes loannis Aubrii, 1601, $2^{\circ}$

Estr. 14, 475.

(wspólopr. z):

$48^{*}$ Cuspinian (Kuspinian) Johann Spiesshaymer, Austria... cum omnibus eiusdem marchionibus, ducibus, archiducibus... Francofurti, typis Wechelianis, apud Claudium Marnium, et heredes loannis Aubrii, $1601,2^{\circ}$

Graesse II, 314.

(współopr. z):

$49^{*}$ Cuspinian (Kuspinian) Johann Spiesshaymer, Viri clarissimi, divi quondam Maximiliani Imperatoris a consiliis et oratoris... Francofurti, typis Wechelianis, apud Claudium Marnium, et heredes loanni Aubrii, $1601,2^{\circ}$

Graesse II, 314.

Lund BU Hist.Allm. Hist.Österr.Rom.

Oprawa: Pergamin koloru kości sloniowej. Na przednieji tylnej okładce wytłoczony superekslibris

herbowy Zygmunta III z orderem Zlotego Runa. Na przedniej okładce nad superekslibrisem wythoczony napis: "IOANNIS CUSPINIANI”.

O.Walde H, 88 .

50 Cyprianus Caecilius, Opera... in tres tomos... Parisiis, apud Sebastianum Niuellium, 1603, $2^{\circ}$

BMC 75, 23.

Västerås Stadsbiblioteket

Oprawa: Skóra brązowa. Na przedniej i tylnej okladce wytloczony zlotem superekslibris herbowy Zygmunta III. Na przedniej okładce wythoczony napis: „OPERUM CYPRIANI TOMUS I”.

Prow.: 1. "Ex bibliotheca Johannis Rosenhane - C.F. Eckleffs exl."

$51^{*}$ Delphinus Julius, In III Galeni artis medicinalis lib. Explanatio... Venetiis, apud lo. Franciscum Camotium ad signum Piramidis, 1557, $4^{\circ}$

(współopr. z): Bassianus L.P., latrologia (poz. 11)

O.Walde II, 87.

$52^{*}$ Delrius (Delrio) Martinus, Disquisitionum magicarum libri sex... Moguntiae, J.Albinum, 1603, $2^{\circ}$

Brunet II, 579.

BKórnicka Cim.F.4204

Oprawa: Pergamin biały. Na przedniej okladce złocony superekslibris Wladysława IV.

53 Denyse Nicolas, Sermones aestivales de tempore... Hagenau, in officina Industrii Henrici Grau, $1510,4^{\circ}$

Benzing 22, poz. 94.

Uppsala UB

Oprawa: XVI w, obcego pochodzenia.

Prow.: 1. "Johannes Valewski 1562 Stockholmiae".

2. „Ex libris Serenissimi Regis Poloniae" (Zygmunta III).

Hartleb s. 159; Sprawozdania s. 88-89; A. Kawecka-Gryczowa s, 117.

54 Dresner Tomasz, Institutionum iuris Regni Poloniae libri IV. ex Statutis et Constitutionibus collecti...

Zamosci, Druk Acad., 1613, $4^{\circ}$

Estr. 15, 307.

BKórnicka sygn. 11832

Prow.: 1. "Vladeslai Sigismundi".

55 Durandus Gulielmus a Sancto Porciano, Super Sententias theologicas Petri Lombardi commentariorum... Parisiis, apud Carolam Guillard, vid. Cl. Chevallonii et Desbois, 1550, $2^{\circ}$

Uppsala UB Teol.Skolas.

Prow.: 1. Biblioteka Zygmunta Augusta. 
2. „Ex libris serenissimi Principis Sigismundi”. (Zygmunta |II).

A. Kawecka-Gryczowa, poz. 417.

56 Errard Johann, Fortificatio, das ist Künstliche und wolgegründte Demonstration und Erweisung...

Francofurti a Mayn, bey Wolffgang Richters, $1604,2^{\circ}$

Stockholm KB

Oprawa: Skóra brazzowa, tloczenia złotem. Pośrodku wythoczony superekslibris herbowy Zygmunta III z orderem Zlotego Runa. Wokó arabeski.

Lindberg s. 119, poz. 21; Sigismund Vasa s. 79, poz. 74.

$57^{*}$ Facius (Faccius) Bartholomaeus, De rebus gestis ab Alphonso primo Neapolitanorum Rege Commentarium libri decem... Lugduni, apud haeredes Sebast. Gryphii, 1560, $8^{\circ}$

Graesse II, 546.

Lund BU Hist. Ital.

Oprawa: Pergamin koloru kości słoniowej. Na przedniej i tylnej okładce złocony superekslibris herbowy Zygmunta III z orderem Zlotego Runa.

O.Walde II, 88 ,

$58^{*}$ Fendt Tobias, Monumenta clarorum doctrina praecipue toto orbe terrarum vivorum collecta passim et maximo impendio cura et industria... Francofurti ad Moenum, Impensis Sigismundi Feirabendi, $1589,2^{\circ}$ Lund BU Biogr.Allm.

Oprawa: Pergamin koloru kości słoniowej. Na przedniej okładce zlocony superekslibris herbowy Zygmunta III z orderem Zlotego Runa.

O.Walde II, 88.

$59^{*}$ Fiaschi Cesare, Trattato dellimbrigliare, attegiare et ferrare cavalli... Venetia, appresso Vincenzo Somosco, $1603,8^{\circ}$

Lund BU Sport.

Oprawa: Pergamin biały

Prow.: 1. „Ex libris Ser ${ }^{\text {mi }}$ Principis Vladislai".

O.Walde II, 88.

$60^{*}$ Fludd Robert, Utriusque cosmi maioris seilicet et minoris methaphysica... T. 1. Oppenhemii, impensis lohannis Theodori de Bry, typis Hieronymii Galleri, $1617,2^{\circ}$

Graesse II, 607.

Lund BU Polygr.(Fol.)

Oprawa: Pergamin kremowy. Na przedniej i tylnej okladce wytloczony superekslibris herbowy Karola Ferdynanda. Wokół wytloczone inicjały: „C.F.P.P."

O. Walde II, 82.

(wspólopr. z:)

$61^{*}$ Fludd Robert, De praeternaturali utriusque mundi historiae. Tomi secundi. Tractatus secundus. Francofurti, typis Erasmi Kempfferi, sumptibus Joan. Theodori de Bry, $1621,2^{\circ}$ (współopr. z):

$62^{*}$ Fludd Robert, Veritatis proscensium in quo aulaeum erroris tragicum dimovetur siparium ignorantiae scenicum complicatur... in appendicae quadam a Joanne Keplero, nuper in fine Harmoniae suae Mundanae edita... Francofurti, typis Erasmi Kempfferi, sumptibus Joan. Theodori de Bry, $1621,2^{\circ}$ (wspólopr. z):

$63^{*}$ Fludd Robert, Anatomiae amphitheatrum effigie triplici, more et conditione varia, designatum, Francofurti, sumptibus Johannis Theodori de Bry, extypographia Erasmi Kemptferi, 1623, $2^{\circ}$ Lund BU Polygr. (Fol.).

64 Folengius loannes Baptista, In canonicas Apostolorum epistolas, videlicet D. lacobi unam, D.Petri duas ac D.loannis primam commentarii. Lugduni, apud Seb.Gryphium, $1555,8^{\circ}$

Ossol. XVI.O.9577.

Prow: 1. Biblioteka Zygmunta Augusta.

2. "Ex libris Serenissimi Principis" (Zygmunta III).

3. „lacobi Holsz. PI. Brester” (XVII).

A.Kawecka-Gryczowa, poz, 426. 
65 Fontana Domenico, Della transportatione dell'Obelisco Vaticano, et delle fabriche di... Papa Sisto V... Roma, appresso Domenico Basa, 1590, $2^{\circ}$

Brunet II, 1329.

Stockholm KB

Oprawa: Skóra czerwona z mozaikowa złoconą dekoracją w stylu włoskim à la fanfare. Pośrodku na czteropolowej tarczy owalnej $z$ herbami Polski i Litwy umieszczona w sercu polowym maka czteropolowa tarcza z herbem Szwecji (bez herbu Gotlandii), bez herbu Wazów. Egzemplarz ofiarowany Zygmuntowi III przez papieża Sykstusa V.

Heymowski, s. 151, 159, poz, 13; Sigismund Vasa, s. 78, poz. 73.

$66^{*}$ Fragoso Baptista, Regimen Reipublicae Christianae, ex Sacra Theologia, et ex utroque iure ad utremque forum tam internum... Lugduni, sumpt. haered. Gabr. Boissat, et Laurentii Anisson, 1641, $2^{\circ}$

Lund BU Fol.Filos.Statsl.

Oprawa: Pergamin biały.

Prow.: 1. "Sermi Caroli Ferdinandi Principis Pola. et Suecia",

"Ex libris Sermi Caroli Ferdinandi Principis Polonia et Suecia”.

O.Walde II, 82.

67 Fulgentius Afer, Opera, librorum multorum accesione locupletata. Antverpiae, apud C. Plantinum, $1573,8^{\circ}$

BMC 117, 367 .

Wilno VUB II-4713.

Oprawa: Skóra brązowa. Na przedniej okladce wytloczony złotem superekslibris herbowy Zygmunta III z orderem Zlotego Runa. Nad superekslibrisem wytloczono: „OPERA D FVLGEN”.

Prow:: 1. „Ex libris R.D. Stanislai Joltok”.

Laucevičius, s. 56, ilustr. 182.

$68^{*}$ Galilei Galileo, De maculis solaribus et stellis circa lovem errentibus accuratior disquisitio ad Marcum Velserum, Augsburg, "Ad insigne Pinus", 1612, $4^{\circ}$

Graesse III, 16.

(współopr. z):

$69^{*}$ Galilei Galileo, Tres epistolae de maculis solaribus. Augsburg, „ad insigne Pinus", $1612,4^{\circ}$

Graesse III, 16

BJ Cim. 5006-5007.

Oprawa: Pergamin biały. Pośrodku wytłoczony złotem superekslibris herbowy Zygmunta III.

Prow.: 1. „Bibliothecae Collegii Tor(unen)is An. 1758”.

Sztuka dworu Wazów w Polsce, s. 69, poz. 128.

$70^{\circ}$ Gebhard Brandanus Heinrich, De principiis (et) dignitate juris prudentiae tractatus philosopho-iuridicus longe pulcherrimus... (Gera), typographo Rutheno-Gerano, $1613,8^{\circ}$

BUW Sd. 28.20.3.2280.

Oprawa: Pergamin czerwony. Na przedniej okladce wytloczone inicjały: "VSP".

Prow.: 1. "Ex libris Sermi Principis Vladislai".

2. "Caroli Ferdinandi".

3. Biblioteka Załuskich.

$71^{*}$ Godefroy Denis (Gothofred Dionysius), Antiquae historiae ex XXVII authoribus contextae libri VI... opera. Argentorati, impensis Lazari Zetneri, $1604,8^{\circ}$

BMC 126, 438.

Lund BU Hist. Allm.

Oprawa: Pergamin biały.

Prow.: 1. "Ex libr: Niewiescinski”.

2. "Danielis Casimiri Krusii”.

3. "Ser.mis Principis Caroli Ferdinandi”.

Marginalia i podkreślenia w tekście.

O.Walde II, 74 .

$72^{*}$ Godefroy Denis, Consuetudines Aurelianae civitatis, Clariss. Iure consulti Pyrrhi Angelbermei Aurelianensis civitatis... Francofurti, ex officina typographica Nicolai Bassaei, 1598, $2^{\circ}$ 
Lund BU Fol.Jur.Rättshail.Fr.

(współopr. z): Statuta Regni Galliae (poz. 138)

O.Walde II, 88.

73 Gorlaeus Abraham, Dactyliotheca seu annulorum sigillarium quorum apud priscos tam Graecos quam Romanos usus... promptuarium... Leyden (?), 1601, $4^{\circ}$

Brunet II, 1671.

Uppsala UB

Oprawa: Pergamin bialy. Na przedniej okladce wytloczony superekslibris herbowy Zygmunta III.

Prow.: 1. „Schering Rosenhane”.

O.Walde II, 89.

$74^{\circ}$ Gratianus Antonius Maria, De bello Cyprio libri quinque. Romae, apud Alexandrum Zanettum, 1624, $4^{\circ}$ Graesse III, 139.

BN XVII.4.8052.

Oprawa: Skóra czerwono-brazzowa (marokin). Na przedniej i tylnej okładce wytloczony złotem superekslibris herbowy Zygmunta Ill z orderem Złotego Runa. Slady po metalowych klamrach.

75 Gravina Domenicus, Vox torturis seu de Florenti usque ad nostra tempora et aliorum sacrarum religionum statu. Coloniae Agrippinae, 1638.

BMC Compact ed. 10, 1156, poz. 871.

Wilno VUB III-418.

Oprawa: Skóra brązowa. Pośrodku wytłoczony superekslibris herbowy Wladysława IV.

Prow.: 1. „Benedictus Szamotulski (Cons.) Reg.".

Laucevičius, s. 56, ilustr. 184.

$76^{\circ}$ Gretser Jacobus, Opera omnia... Ingolstadii, ex typographo Ederiano, apud Elisabethum Angermariam viduam, $1616,2^{\circ}$

Lund BU (Fol.) Teol.Rom.Kat.

Oprawa: Skóra brazowa. Na przedniej i tylnej okladce wytłoczony zlotem superekslibris herbowy Zygmunta III $z$ orderem Zlotego Runa.

O.Walde II, 88.

77 Gregorius Nyssenus, Opera... de Graeco in Latinum sermonum conversa... 2 ed. Basileae, per Eusebium Episcopium, et Nicolai fratris haered., 1571, $4^{\circ}$

Graesse III, 148.

Västerås Stadsbiblioteket

Prow: 1. „Ex libr: N. Niewiescinski. A(o) Di 1586".

2. „Johan Albini".

3. „M. Aleksandri Glaserj Wartebergj”.

4. „Ex libris Caroli F(erdinandi)”.

78 Groicki Bartlomiej, Porządek sądów y spraw mieyskich prawa maydeburskiego... Cracoviae, druk. Franc. Cezarego, $1629,4^{\circ}$

Estr. 17, 406

Ossol. XVII.2780.

Oprawa: Pergamin biały. Na przedniej i tylnej okladce wytloczony zlotem superekslibris $z$ herbem Wazów.

$79^{\circ}$ Helmond, Chronica Slavorum seu Annales... Accessit item Historia vita Henrici IIII... Francofurti, apud Andream Wechelum, $1581,2^{\circ}$

Brunet II, 91.

Lund BU Hist. Tysk. Medelt.

Oprawa: Pergamin koloru kości sloniowej. Na przedniej okladce wytloczony zlotem superekslibris herbowy Zygmunta III z orderem Zlotego Runa.

O.Walde II, 88.

$80^{\circ}$ Hippocrates, Principis libelli aliquot, ad antem medicam praeparatorii, recens per lanum Comarium... latina lingua consripti... Basileae, ex officina lo. Oporini, 1543, $4^{\circ}$

Short Cat. 406. 
Lund BU Klass.Graek.

(wspólopr. z): Bassianus L.P., latrologia. (poz. 11).

O.Walde II, 87.

81 Horae ad usum Ecclesiae Romanae (tzw. Modlitewnik królowej Bony). rkps, Florencja 1492, $8^{\circ}$ pergamin

Zamek Królewski w Warszawie.

Oprawa: XIX w.: czerwony aksamit pokryty srebrnym filigranem. Na przedniej okładce medalion z emalii białej Orzeł na czerwonym tle. Na tylnej okładce medalion z Pogonią i herbem Sforzów.

Prow.: 1. (Wazowie).

2. Biblioteka wilanowska. (Ręką S. Potockiego napisana w i. franc. historia Modlitewnika).

3. Zamek Królewski w Warszawie.

4. WI. 1939-1959 zdeponowany w Kanadzie.

5. Muzeum Narodowe w Warszawie.

6. w 1984 r. (6.VI.) przekazany Zamkowi Królewskiemu.

J. Lileyko, Dawne zbiory Zamku Królewskiego w Warszawie. Warszawa 1983, s. 34-35.

82 Hosius Stanisław, Opera... Antverpiae, in aed. vid. et haer. lo Stelsii, 1571, $2^{\circ}$

Estr. 18, 288.

Stockholm KB

Prow.: 1. Biblioteka Zygmunta Augusta.

2. "Ex libris Sermi Sigismundi Regis Poloniae et Suetiae".

3. „Ex liberalitate Sereniss. Gustavi Adolphi donatum venerabili D. Engelberto Lulensium pastori paterno affini carissimo lohannes Bureus dddt".

4. "Kostar 3 /gr Koppermint Stockholm d.29 Febru.1752".

Lindberg, poz. 20; A.Kawecka-Gryczowa, poz. 441.

$83^{*}$ Inchofer Melchior, Annales Ecclesiastici Regni Hungaricae... Romae, typis Ludovici Grigniani, 1644, $2^{\circ}$ Graesse II, 269.

Lund BU Kyrkohist. Österr.(Fol.).

Oprawa: Pergamin kremowy. Na przedniej i tylnej okladce wyttoczony superekslibris Karola Ferdynanda $z$ inicjatami „C.F.P.P.”.

O.Walde II, 82.

84 losephius Flavius, Opera. (Ed. Arnoldus Peraxylus Arlenius). Basileae, Hier. Froben et Nic. Episcopius, $1544,2^{\circ}$ (Tytul także w j. greckim, tekst grecki).

Uppsala BU Bokband 1500-t. Polen. Fol.6.

Prow.: 1. Biblioteka Zygmunta Augusta.

2. "Ex libris Serenis-i Principis" (Zygmunta III).

O.Walde II, 86; A. Kawecka-Gryczowa, poz. 765.

85 Jovius Paulus (Giovio Paolo), Historiarum sui temporis tomus primus. Florentiae, in offic. Laur. Torrentini, $1550,2^{\circ}$ (wol. 2).

Uppsala UB Allm. Hist. nyer. (Rr 3).

Prow.: 1. Biblioteka Zygmunta Augusta.

2. „Ex libris Seren-i Prin-is”, "Ex libris Sermi Regis Sigismundi" (Zygmunta III).

O.Walde II, 86; A. Kawecka-Gryczowa, poz. 768.

$86^{*}$ Justynianus Petrus, Rerum Venetarum ab Urbe Condita ad annum MDLXXV Historia... Argentorati, sumptibus Lazari Zetzneri Bibliop, $1610,2^{\circ}$

BMC 169, 390.

Lund BU Hist. Ital. Lokal hist. (Venadig).

Oprawa: wspókczesna, kolorowy karton.

Prow: 1. „Ex libris Ser ${ }^{m i}$ Principis Caroli Ferdinandi".

O.Walde II, 83.

$87^{*}$ Knapski Grzegorz, Thesauri polono-latino-graeci... Tomus

tertius. Cracoviae, Fr. Cezary, $1632,4^{\circ}$

Estr. 19, 337.

BUW 4.10.3.10. 
Oprawa: Skóra (odcień naturalny). Pośrodku wythoczony superekslibris z herbem Wazów i orderem Zlotego Runa.

Prow: 1: „Ex Biblioteca Monasterij s. fvnis in Caluo Monte Empsk. Cracou. R. 9 A ${ }^{\circ} 1635^{\prime}$.

2-gi egz::

Bibl. kopacińskiego w Lublinie P-17-q-149.

Oprawa: Skóra brazowa. Pośrodku wytloczony superekslibris Wladysława IV.

Prow.: 1.„Emptus anno 170931 Jan... (zakreślone) a dno Neuman.".

2. "Ex libris Joannis Wybranowski” (nazwisko zakreślone).

3. "Ex Biliotheca Adal(berti) Laszowi(cz)".

4. "Bibliothecae Collegii Lucoviensis S(cholarum) P(iarum) 1825 anno".

88 La Bigne Margarinus, Sacrae bibliothecae Sanctorum Patrum seu scriptorum ecclesiasticorum probabilium, tomi novem... Parisiis, $1589,2^{\circ}$ (5 wol.)

Västerås Stadsbiblioteket

Oprawa: Skóra brązowa. Na przedniej okładce wytloczony zlotem superekslibris herbowy Zygmunta III. Wokół stylizowane ornamenty roślinne.

Prow.: 1. "Ex lib. C.F. Muhrbeck Carolicor. 1770".

Lindberg, s. 120.

$89^{\circ}$ Lapini Frosino, Institutionum Florentina Lingua libri duo. 2 ed. Florentiae, apud Juntas, $1574,8^{\circ}$

BMC 184, 244.

BUW 28.2.12.15.

Oprawa: Pergamin biahy.

Prow.: 1. "Ser ${ }^{\mathrm{mi}}$ Principis Caroli Ferdinandi".

2. Biblioteka Zaluskich

$90^{*}$ Lazius Wolfgang, De aliquot gentium migrationibus, sedibus fixis, reliquiis, linguarumque... libri XII. Basileae, per loannen Oporinum, $1557,2^{\circ}$

Graesse IV, 130.

Lund BU (Fol.) Arkeol. Allm.

Oprawa: Pergamin biahy. Na przedniej okładce, na dole, wytloczono zlotem rok oprawy: „1595”.

Prow.: 1. "Ex lib. Niewiescinski".

2. "Ex libris Ser ${ }^{\mathrm{mi}}$ Principis Caroli Ferdinandi".

Podkreślenia w przedmowie.

O.Walde II, 74

91 Lerbeke Hermannus de, Cronicon comitum Schawenburgensium... Francofurti, Erasmi Kempfferi, $1620,4^{\circ}$

BMC 190,4

BN XVII.3.21886.

Oprawa: Pergamin bialy. Na przedniej okladce wytloczony superekslibris Wazów z orderem Zlotego Runa oraz inicjały: „C.F.P.P.”.

Prow.: 1. „dar Henryka Bukowskiego".

2. "Muzeum w Rapperswilu"

Sztuka dworu Wazów w Polsce, s. 107, poz. 293.

$92^{*}$ Lipsius lustus, Saturnalium sermonum libri duo, qui de gladiatoribus. Antwerpiae, ex officina Plantiniana, apud Joannem Moretum, 1594, $4^{\circ}$

(wspólopr. z):

$93^{*}$ Lipsius Justus, Admiranda sive De Magnitudine.Romana libri quáttuor... Antverpiae, ex officina Plantiniana, apud Joannem Moretum, $1604,4^{\circ}$

(współopr. z):

$94^{*}$ Lipsius Justus, Dissertatiuncula apud princeps: item C. Plinii panegyricus Liber Traiano dictus... Antverpiae, ex officina Plantiniana, apud Joannem Moretum, 1594, $4^{\circ}$

BN XVI.Qu. 4004-4006.

Oprawa: Pergamin kremowy. Na przedniej i tylnej okładce wytloczony superekslibris herbowy Zygmunta III z orderem Zlotego Runa.

Prow.: 1. "Ex libris Ser ${ }^{\mathrm{mi}}$ Principis Vladislai". 
2. "Ex Donat. S.R.M ${ }^{\text {mis }}$ Domus prof. Vars. Soc. Jesu 1660".

3. Exlibris: „Z Księgozbioru Zygmunta Czarneckiego”, ręczny zapis "N.K.2150".

$95^{\circ}$ Lipski Andrzej, Practicarum obsenationum ex Jure Civili et Saxonico collectarum, et ad stylum usumque Judiciarum Curiae Regalis accomodatarum Centuria prima... Rigae Livonum, excudebat Nicolaus Mollinus, $1602,4^{\circ}$

Estr. 21, 316.

Biblioteka Kapitulna w Łowiczu, sygn. 1173.

Oprawa: Pergamin koloru kości słoniowej. Na przedniej okladce wytloczony superekslibris herbowy Zygmunta III. Bardzo skromne tloczenie zlotem. Na tyinej okladce w owalnej ramce ozdobnej wythoczony ekscentryczny kartusz herbowy ze znamieniem Grabie.

Prow.: 1. J.A. Lipski.

2. "Post Perillustri Paprocki”.

3. "Ecclesiae Collegiatae Lovicensis".

Na k. dedykacyjnej niewyraźne zapisy rękopiśmienne atramentem.

Z. Skielczyński, Superekslibrisy z Biblioteki Kapitulnej w Łowiczu, "Studia Theologica Varsaviensa”, R.28:1990 nr 1, s. $251-252$.

96 Lycosthenes Conradus (Wolffhart Konrad), Prodigiorum ac ostentorum chronicon. Basileae, per Henr. Petri, Aug. 1557, $2^{\circ}$

Skokloster

Prow: 1. Biblioteka Zygmunta Augusta.

2. "Ex lib(is Serenissimi) P(rincipis)" (Zygmunta III).

3. "Johan Mö̈r daje Johannesowi Bureusowi 29 VI 1600".

4. "Johan. Messenii 1626".

5. "Carl Gustaf Bielke”.

6. "Sten Bielke".

O. Walde II, 86: A. Kawecka-Gryczowa, poz. 941.

$97^{*}$ Łubieński Stanistaw, Opera posthuma, historica, historico-politica... Antverpiae, apud Joannem Meursium, 1643, $2^{\circ}$

Estr. 21, 441.

BN XVII.4.3274.

Oprawa: skóra czerwona (marokin) z bogato złoconą ornamentyką. Na przedniej i tyinej okładce wytloczony ziotem superekslibris herbowy Wazów (Wladysława IV): czteropolowa tarcza z herbami Polski i Litwy, na niej tarcza z herbem Szwecji i Gotlandii. W polu sercowym herb Wazów. Ślady po skórzanych wiązaniach.

Prow.: 1. "Gustavus Adolph. de la Gardie".

2. "Ex Libris Cap. (?) Lodunevolb. (?) 1692" (zapis nieczytelny, przekreślony).

3. "Ex libris Georgiy Joan Grunowski" (?).

4. "Domuiti (?) Varsav. SJ Prov. Polona".

5. "Ex liberalitae... Centis/Dni Doctoris Sethi, Domino Powöhl 1812".

6. "Ex libris V.C. Moncta 1812".

7. "Dar Henryka Bukowskiego".

$98^{*}$ Magini Giovanni Antonio, Novae coelestium orbium theoricae congruentes cum observationibus $N$. Copernici. Venetiis, ex officina Damiani Zenarii, 1589, $4^{\circ}$

Graesse IV, 336.

Lund BU Astron.Allm.

W tekście liczne podkreślenia.

(współopr. z):

$99^{*}$ Magini Giovanni Antonio, De planis triangulis liber unicus... Venetiis, apud lo.Baptistam Ciottum. $1592,4^{\circ}$

Graesse IV, 336.

Lund BU Astron. Allm.

(współopr, z): 
$100^{\star}$ Magini Giovanni Antonio, Tabula tetragonica seu quadratorum numerorum com suis radicibus... Venetiis, apud lo. Baptistam Ciottum, 1592, $4^{\circ}$

Graesse IV, 336.

Lund BU Astron. Allm.

Oprawa: Pergamin bialy.

Prow.: 1. "Danielis Casimirij Krusij”.

2. „Ex Libris Serenissimi Principis Caroli Ferdinandi”.

3. "Match. $4^{\circ} \mathrm{N}^{\circ} 294^{\prime \prime}$ (przekreślone), "Match. 443".

O.Walde II, 76 .

$101^{*}$ Messen (Messenius) Jan, Genealogia Sigismundi tertii... Dantisci, viduae Guillemthanae, 1609 (1608), $16^{\circ}$

Estr. 22, 305.

BN W.19291.

Oprawa: Pergamin koloru kości sloniowej. Na przedniej i tylnej okladce wytloczony złotem superekslibris herbowy Zygmunta III z orderem Zlotego Runa. Ślady po wiązaniach.

Prow.: 1. "Erasmas a Landen".

2. pieczęć: "Biblioteka Pulawska”.

3. Biblioteka Potockich w Wilanowie.

Sztuka dworu Wazów w Polsce, s. 70, poz. 129 podano r. wyd. 1612.

$102^{*}$ Meteren Emmanuel von, Historia Belgica... (Antverpiae, 1597) $2^{\circ}$

Brunet III, 1677.

Lund BU Hist. Nederl. (Fol.).

Oprawa: Pergamin kremowy. Na przedniej okladce wytloczone inicjały: „VSP".

O.Walde II, 88.

103 Morus Thomas, Lucubrationes, ab innumeris mendis repurgatae. Basileae, apud Episcopum, 1563, $8^{\circ}$ Östersund Jamtland Läns Bibliotek

Prow.: 1. "Georg Scherhackl ab Hartenfelds... 96".

2. "Us. Princ. Karl Ferdinands bibliot. Jazdow (vid. Warschau)" (Karola Ferdynanda).

104 Niszczycki Krzysztof Karol, luris Universi Conclusio ad ... Vladislaum... Romae, 1611, $4^{\circ}$

Estr. 23, 161 podaje m.wyd.: Maceratae, typis Seb. Martellini.

Linköping

Oprawa: Skóra czerwonobrunatna (safian). Na przedniej okładce wytloczony stylizowany Orzeł w koronie, na którym umieszczono czteropolową tarczę z herbami Szwecji i Gotlandii. W polu sercowym mala tarcza z herbem Wazów. (Egzemplarz Whadysława IV).

Collijn, s. 395; Sprawozdania..., s. 315; Heymowski, s. 151, 159.

$105^{*}$ (Ordnungen) Der Erst Theyl. Aller des Heyligen Römischen Reichs Ordnungen gehaltener Reichsstäge und Abschiedt. Teil 1-2. Mainz, durch Franz Behem, 1560, $4^{\circ}$ (2 wol.).

Lund BU (Fol.) Jur. Rättskan. Tyskl.

Oprawa: Pergamin koloru kości sloniowej. Na przedniej i tylnej okladce wytloczony zlotem superekslibris herbowy Zygmunta III z orderem Zlotego Runa.

O.Walde II, 88.

106 (Ossoliński Jerzy), Statuta Inclyti ac Heroici Ordinis Equitum Immaculatae Virginis. $4^{\circ}$

Estr. 23, 483.

Druk na pergaminie. Rzadkość oznaczona pięcioma gwiazdkami,

BCzart. saf.33699 I.

Oprawa: Skóra wiśniowa, kozłowa. Na przedniej okładce wytloczony superekslibris Wladysława IV. Na tylnej okładce - Orzeł z okresu Wazów.

Prow.: 1. Biblioteka Jana III Sobieskiego.

2. Biblioteka Załuskich.

3. Biblioteka Porycka.

4. Biblioteka Stanisława Augusta Poniatowskiego.

5. T. Czacki, 1798 r.

107 Papa Guido (de la Pape), Consilia... cum repertorio. Lugduni, in offic. lo Crespin, $1533,8^{\circ}$ 
Uppsala UB

Prow.: 1. Biblioteka Zygmunta Augusta.

2. "Ex libris Serenissimi Principis" (Zygmunta III).

O.Walde II, 59; A. Kawecka-Gryczowa. poz. 241.

108 Papa Guido (de la Pape), Singularia... Lugduni, ex offic. Nic. Petit et Hect. Penet, $1533,8^{\circ}$

Uppsala UB

Prow.: 1. Biblioteka Zygmunta Augusta.

2. "Ex libris Serenissimi Principis" (Zygmunta III).

A. Kawecka-Gryczowa, poz. 242.

$109^{*}$ Paradinus (Paradin) Gulielmus, De motibus Galliae, et expugnato receptoque Itio Caletorum anno 1558. Lugduni, apud loan. Tornaesium et Gul. Gazeium, 1558, $8^{\circ}$

Lund BU Hist. It.

O. Walde II, 88

(wspólopr. z): Facius B. De rebus gestis... (poz. 57)

110 Pennotus (Pennotto) Gabriel, Generalis totius sacriordinis clericorum canonicorum historia... tripartita. Coloniae, Gerhard Gresenbruck, $1630,2^{\circ}$

BGdańska PAN

Oprawa: Skóra brązowa. Na przedniej okładce wytloczony herb Wazów.

Prow.: 1. "Ex libris Senatus Gedanensis".

111 Persona Gobelinus, Cosmodromium, hoc est chronicon universale (com)plectens res ecclesiae et re(ipublice)... Francofurti, apud Andreae Wecheli hered. Claudium Marnium et Joannem Aubrium, $1599,4^{\circ}$

Short Cat. 684.

Västeås Stadsbiblioteket

Prow.: 1. "Ex libr. N. Niewiescinski 1602".

2. "Dan Casim. Crusii”.

3. „Ex libris ser:mi Caroli Ferdinandi”.

$112^{*}$ Petavius (Petau) Dionysius (Denis), De doctrina temporum ... Lutetiae Parisiorum, sumptibus Sebastiani Cramoisy, $1627,2^{\circ}$

Brunet IV, 528.

Lund BU Kronol. (Fol.).

Oprawa: Pergamin kremowy. Na przedniej i tylnej okładce wytloczony superekslibris Karola Ferdynanda $z$ inicjalami: „C.F.P.P.”.

Prow.: 1. „Ex libris Sermi Caroli Ferdinandi Principis Pol(oni)ae et Suetiae”.

O.Walde II, 83.

$113^{\circ}$ Plater Felix, De corporis humani structura... Basileae, typis Conradi Waldkirchi, 1603, $2^{\circ}$

Lund BU Med.Anat.

Oprawa: Pergamin kremowy. Na przedniej i tylnej okładce wytloczony superekslibris herbowy Zygmunta III z orderem Zlotego Runa.

O.Walde II, 88.

$114^{*}$ Plautus Titus Maccius, M.Plauti Comoediae XX... Basileae, (apud And. Cratandrum), 1523, $8^{\circ}$ BUW 28.11.11.5.

Oprawa: Skóra brazowa, tloczenie złotem.

Prow.: 1. „Danielis Casimiri Krusij Cracoviae emptus 15 gr.”.

2. "Ser(enissi)mi Principis Caroli Ferdinandi”.

3. "Ex libris Alb(erti) Basilij Scotnicij Emptus Crac. 25 Marci 1668 f.9".

4. Biblioteka Załuskich.

$115^{*}$ Pomodoro Giovanni, Geometria pratica tratta dagl'Elementi d'Euclide et altri ... Roma, appresso Stefano de Paolini, $1599,2^{\circ}$

Graesse V, 399.

BN XVI.F.3178.

Oprawa: współczesna: karton beżowy, grzbiet pokkryty skóra brazową. 
Prow.: 1. "Ex libris Ser ${ }^{m i}$ Principis Vladislai".

$116^{*}$ Pontanus Johann (Pontano Giovanni), Originum francicarum libri VI in quibus Praeter Germaniae ac Rheni Chorographiam... Hardervici, ex officina Thomae Henrici impensis Henrici Laurencii, Amstelodamensis Librarii, $1616,8^{\circ}$

Lund BU Arkeol.Fr.

Oprawa: Pergamin kremowy. Na przedniej i tylnej okładce wytloczony złotem superekslibris herbowy Zygmunta III.

O. Walde II, 88.

117 Porta Giovanni Battista, De humana physiognomia ... Neapoli, 1603, $4^{\circ}$

Brunet IV, 826.

Uppsala UB

Oprawa: Pergamin kremowy. Na przedniej okładce wytloczony superekslibris herbowy Wazów.

Prow.: 1. „Sten. Bielke”.

2. B. Oxenstierna.

Konung Sigismund, s. 328.

$118^{*}$ Powodowski Hieronim, Christologiae seu Sermonum de Christo. Pars Prior. Cracoviae, in officina Andreae Petricovii, 1602, $4^{\circ}$

Estr. 25, 188 .

BN XVII.3.1699.

Oprawa: Pergamin biały. Na przedniej i tylnej okładce wythoczony superekslibris herbowy Zygmunta III z orderem Zlotego Runa. Egz. po konserwacji.

Prow:: 1. „Nicolaus Popławski".

2. pieczęć: „Bibliotheca OO Zamoyski”, ekslibris: „Z Biblioteki Ordynacyi Zamoyskiej roku 1815”.

119 Psalterium chorale una cum Hymnario toto iuxta morem et ritum... Ecclesiae Romanae ... Venetiis, Petr. Liechenstein, $1558,2^{\circ}$

Uppsala UB Teol.Stor. Folio $(64,16)$.

Prow: 1. Biblioteka Zygmunta Augusta.

2. "Ex libris Sermi Regis Sigismundi" (Zygmunta III).

O.Walde II, 86; A. Kawecka-Gryczowa, poz. 541.

$120^{*}$ Puccitelli Virgilio, II ratto d'Elena, dramma musicale ... Varschoviae, apud Joannem Trelpiński, 1638, $16^{\circ}$ Estr. 25, 398.

BJ Cim. 5508.

Oprawa: Pergamin biały. Na przedniej i tylnej okladce wytloczony superekslibris herbowy Władyslawa IV.

$121^{*}$ Radziwilł Mikołaj Krzysztof, Hierosolymitana peregrynatio ... Brunsbergae, apud Georgium Schönfels, $1601,4^{\circ}$

Estr. 26, 89.

Lund BU Res.Palest.

Oprawa: Pergamin koloru kości stoniowej. Na przedniej okladce wytloczony złotem superekslibris herbowy Zygmunta III z orderem Zlotego Runa.

O. Walde II, 88.

$122^{*}$ Reinhold Erasm, Prutenicae tabulae coelestium motuum ... Tubingae, apud Osuualdum et Gregorium Gruppenbachios, 1571, $4^{\circ}$

Estr. 26, 197.

BUW 28.5.6.14.

Oprawa: Pergamin bialy.

Prow.: 1. "Sum Ex libris M. Michaelis de Rud hor ..."

2. "Ex libris Serenissimi Principis Caroli Ferdinandi".

3. „Canonicus Warszawiensis Excellentis ... maticus fuit opera ipsius testantur ... sum(m)a eum diligentia scripsit".

4. Biblioteka Załuskich. 
$123^{*}$ Renou Jean de, Institutionum Pharmaceuticarum libri quinque ... Parisiis, apud viduam Gulielmi de la Noué et Dionys. de la Nouë, $1608,8^{\circ}$

Lund BU Med.Farm.

Oprawa: Pergamin kremowy. Na przedniej okładce wytloczony superekslibris herbowy Zygmunta IiI z orderem Złotego Runa.

O.Walde II, 88 .

$124^{*}$ Resta Francisco, Meteorologia de Igneis Aereis Aqueisque Corporibus. Roma, apud Franciscum Montam, 1644, $8^{\circ}$

BMC 273, 475 .

BUW 3.6.3.5.

Oprawa: Pergamin kremowy. Na przedniej i tylnej okładce wytłoczony superekslibris Karola Ferdynanda.

Prow.: 1. „Ex (Bibliotheca) Princ(ipis) Regii", "Pol”, „Ex libris Ser. Principis Carali Ferdinandi”.

2. pieczęć: "A(ndreas) Z(aluski) E(piscopus) $\mathrm{C}$ (racoviensis)".

$125^{*}$ Ribadeneira Petro, Princeps Christianus adversus Nicolaum Machiavellum ... Antverpiae, apud loachimum Trognaesium, 1603, $2^{\circ}$

Estr. 26, 292.

Lund BU Filos.Stats|. Rar.saml.

Oprawa: Skóra brązowa. Na przedniej i tylnej okładce wythoczony kolorowy (niebiesko-żólty, biato-czerwony) superekslibris herbowy Zygmunta III okolony lańcuchem orderu Zlotego Runa. Wokól stylizowane obramowania, ozdobny grzbiet, złocone brzegi kart. Na przedniej okladce nad superekslibrisem zlocony napis: "Ser ${ }^{\text {mo }}$ Poloniae et Swetiae Regi etc. Sigismundo tertio". Pod superekslibrisem: „ANNO 1604”. Egzemplarz po konserwacji.

126 Richeomus Ludwik (Richeomo Louis), Expostulatio apologetica ad Henricum IV ... Lugduni, apud Horatium Cardon, $1606,8^{\circ}$

BMC 275, 330 .

Stockholm KB

Prow.: 1. "Danielis Casim. Krusio ... A. 1636".

2. "Ex Libris Ser:mi Principis Caroli Ferdinandi".

O.Walde II, 76 .

$127^{*}$ Rosino Johann, Romanorum antiquitatum libri decem... Basileae, ex officina haeredum Petri Pernae, per Conradum Waldkirch, $1583,2^{\circ}$

Short Catalogue 758.

Lund BU Arkeol.Rom.

Oprawa: Pergamin kremowy. Na przedniej okładce wytloczony superekslibris Karola Ferdynanda oraz inicjaly: „C.F.P.P.”.

O.Walde II, 76 .

$128^{\circ}$ Rudomina Dusiatski Joannes, Ilustriora theoremata et problemata mathematica et opticis... Wilno, typis Academica, 1633, $4^{\circ}$

Estr. 26, 470 .

BUW Sd.714.474.

Oprawa: Pergamin czerwony, thoczenia zlote z dodatkiem srebra. Superekslibris z herbami Polski i Litwy wzorowany na superekslibrisie Zygmunta Augusta. Superekslibris Wadyslawa IV nietypowy.

Prow.: 1. „Inscriptus Catalogo Libri Colleg. Caliss. Soc. Jesu”.

2-gi egz:

B.Czart, 57061 III

Oprawa taka sama jak w BUW.

Prow.: 1. Egzemplarz był przed r. 1830 w Pulawach.

$129^{\circ}$ Rüff Jacob (Rueff lacobus), Libellus de tumoribus phlegmaticis non naturalibus. Tiguri, apud Frosch(auer), 1556, $4^{\circ}$

Short Catalogue 759.

Lund BU Med.Svulst.

O.Walde 11,87 . 
(Wspólopr. z): Bassianus L.P., latrologia. (poz. 11).

$130^{\circ}$ Ruvius Antonius, Commentari in octo libros Aristotelis de physico auditu ... Coloniae Agrippinae, sumptibus Antonii Boetzerii, 1610, $4^{\circ}$

BMC 181,91.

Lund BU Filos.

Oprawa: Pergamin biahy.

Prow: 1. "Ex libris Serenissimi Principis Caroli Ferdinandi”.

O.Walde II, 83.

131 Sabellicus Marcus Antonius Coccius, Decades rerum Venetarum N. Venetiis, Andr. Torresanus, $1487,2^{\circ}$

Graesse VII, 202.

Uppsala UB 34:13.

Prow.: 1. Biblioteka Zygmunta Augusta.

2. "Ex libris Serenis. Prin-pis Sigismundi” (Zygmunta III).

O.Walde II, 86; A. Kawecka-Gryczowa, poz. 803.

$132^{*}$ Savonarola Joannis Michel, Practica cononica. Lugduni, apud Sabastianum Honoratum, $1560,16^{\circ}$ Graesse VI, 286.

Lund BU Med.Patol.

Oprawa: Pergamin biały. Na przedniej i tylnej okładce wytloczony zlotem superekslibris herbowy Zygmunta III z orderem Zlotego Runa. Egzemplarz po konserwacji.

Prow.: 1. „Ex 2: Bergnerska saml.".

O.Walde II, 88.

133 Sigonius Carolus, Fasti consulares ac triumphi acti a Romulo Rege usque ad Ti. Caesarem ... Venetiis, apus Pau. Manutium, 1556, $2^{\circ}$

Graesse VI, 403.

Uppsala UB Hist.Rom. Urk. (E:14).

Prow.: 1. Biblioteka Zygmunta Augusta.

2. "Ex libris Serenissimi Principis" (Zygmunta III).

O.Walde II, 86; A. Kawecka-Gryczowa, poz. 804.

134 Skarga Piotr, Kazania na niedziele y święta calego roku. Kraków, Druk. Andrzeja Piotrkowczyka, $1595,2^{\circ}$

Estr. 28, 142.

Uppsala UB

Oprawa: Skóra czerwonobrunatna ze złoceniami. Pośrodku wyttoczony superekslibris herbowy Zygmunta III.

Prow.: 1. "G. De la Gardie".

O.Walde II, 89; Heymowski, s. 150, 159 poz. 9; Lindberg, s. 118, poz. 15.

$135^{*}$ Sokolowski Stanisław, Officia propria Patronum Regni Poloniae ... Antverpiae, ex officina Plantiniana, apud viduum et Filios Joannis Moreti, $1614,2^{\circ}$

Estr. 29, 16.

Lund BU Teol.Liturg.Rom.lat.

(współopr, z): Breviarum Romanum. poz. 25).

136 Sokołowski Stanisław, Opera, Cracoviae, In Architypographia Lazari, 1591, $2^{\circ}$

Estr. 29, 20-21.

BCzart. Cim. 772 III.

Oprawa: Skóra brązowa cielęca. Toczenia złote. Na przedniej i tylnej okładce superekslibris herbowy Zygmunta III. Oprawa datowana: ${ }_{n} 1591$ ".

Prow.: Książka byla przed r. 1831 w Pulawach.

Sztuka dworu Wazów w Polsce, s. 60, poz. 125.

137 Stadius Joann, Ephemerides Novae et exactae. Joannis Stadii Leonnovthesi ab anno 1554 ad annum $1570 \ldots$ Coloniae Agrippinae, apud haeredes Arnoldi Birkmanni, 1556, $4^{\circ}$ Graesse VI, 476. 
BCzart. Cim. 2432 I.

Oprawa: Pergamin biahy, thoczenia złote. Na przedniej i tylnej okladce wythoczony superekslibris Zygmunta III.

Sztuka dworu Wazów w Polsce, s. 69, poz. 126.

$138^{*}$ Statuta Regni Galliae iuxta Franconum Burgundionum Gothorum et Anglorum ... Francofurti, impensis loannis Trevtelli, Bibliop. 1612, $2^{\circ}$

Lund BU Jur.Rottskat.Fr. (Fol.).

Oprawa: Pergamin koloru kości sloniowej. Na przedniej i tylnej okładce wytloczony zlotem superekslibris herbowy Zygmunta III z orderem Zlotego Runa.

Prow.: 1. „Bielke”.

O.Walde II, 88.

139 Suetonius Tranquillus Caius, Duodecim Caesares cum Philippi Beroaldi Marcique item Antonii Sabellici commentariis ... Lugduni, lo. Frellonius, $1548,2^{\circ}$

Graesse VI, 522.

Prow.: 1. Biblioteka Zygmunta Augusta.

2. „Ex libris Sereniss' Principis” (Zygmunta III).

Lindberg, poz. 21; A. Kawecka-Gryczowa, poz. 806.

140 Szczerbic Pawel, Promptuarium statutorum omnium et constitutionum Regni Poloniae ad usum domesticum per ... conscriptum ... 1593, $2^{\circ}$ rkps

Uppsala UB

Oprawa: Skóra czerwona, złocone ornamenty. Na przedniej okładce wytloczony superekslibris herbowy Zygmunta III.

Prow.: 1. "Magnus De la Gardie”.

O.Walde II, 89; Sprawozdania... s. 166, poz. 282.

141 Talmud (Epitome Hebraicum ex Talmut). Venetiis, apud Marcum Ant. Jushmanum (Giustinianium), $1550-1551,2^{\circ}$ (2 wol.).

Uppsala UB Obr. 53:65, 53:66.

Prow.: 1. Biblioteka Zygmunta Augusta.

2. "Ex libris Ser. Princ." (Zygmunta III).

3. "Liber Johannis Burei ex Liberalitate regia" (Gustawa Adolfa).

A.Kawecka-Gryczowa, poz. 504.

142 Terentius Afer Publius, Comoediae sex, tum ex Donati commentariis ... Parisiis, ex officina Roberti Stephani typographi Regii, $1514,4^{\circ}$

Graesse Vl/2, 56.

Lund BU Klass.Lat.

Oprawa: Pergamin biały ze zloceniami.

Prow:: 1. „Daniel Casimirus Krusius. The: it. IVD: CVSTOS. Wrat”.

2. „Ex Libris Ser ${ }^{\mathrm{mi}}$ Principis Caroli Ferdinandi”.

O.Walde II, 76.

143 Thomas de Aquino, Divi Thomae Aquinatis... tomus decimus complectens Primum partem Summae Theologicae, Venetiis, Scotus, $1593,2^{\circ}$

Graesse $\mathrm{VI} / 2,140$.

Wawel Cim.20.

Oprawa: Pergamin biały. Na przedniej i tylnej okładce wytłoczony złotem superekslibris Wazów.

Prow.: Egzemplarz zakupiono w 1936 r. w Antykwariacie.

$144^{*}$ Thomas de Aquino, Opera omnia... Venetiis, apud Dominicum Nicolinum et Socios, (1593), $2^{\circ}$ (T.13-14).

BUW Sd.602.433 XIII-XIV.

Oprawa: Skóra czerwona kozłowa (safian), tłoczenie złotem, złocone obcięcia. Na przedniej i tylnej okładce superekslibris herbowy Zygmunta III z orderem Zlotego Runa.

Prow.: 1. Andrzej Stanislaw Zahuski (1740 r.).

2. Józef Andrzej Zaluski.

M.SipayHlo, s. 248. 
$145^{*}$ Tritonius M. Antonius Utinensis, Mythologia ... Bononiae, ex officina Alexandri Benecii, et Joannis Rubei Sociarum, $1560,8^{\circ}$

BMC 329, 397.

Lund BU Religionvet. greck.Rom.

O.Walde II, 88.

(wspólopr. z): Bracelli J., De bello neapolitano... (poz. 23).

146 Trzebicki Andrzej, Manipulus orationem ab eruditis vitis Polonicae nationis diversis temporibus et occasionibus scriptarum. Romae, haeredum Francisci Corbelletti, 1639, $4^{\circ}$

Estr. 31, 356.

BKórnicka 2384.

Prow.: 1. Wladystaw IV (?).

2. "Rafal Leszczyński”.

147 Valla Georgius, Opus de expetendis et fugiendis rebus, in quo continentur: De arithmetica... Venetiis, in aed. Aldi Romani imp. ac studio loannis Petri Vallae filii, $1501,2^{\circ}$ (2 wol.).

Uppsala UB 42, $11,1$.

Prow.: 1. lac. i greckie zapiski w t.2. (nieliczne) z wczesnego XVI w.

2. "Ex libris serenissimi Regis Sigismundi" (Zygmunta III).

A. Kawecka-Gryczowa, poz. 722.

$148^{*}$ Vegetius Flavius Renatus, De re militari libri quattuor (et alia). Lutetiae, apud Christ. Wechelum, $1532,2^{\circ}$

BUW Sd.602.138 cim.

Prow.: 1. Biblioteka Zygmunta Augusta.

2. „Ex libr. Serenis. Prin:is" (Zygmunta Iil), (w BUW zapis ten przypisano Karolowi Ferdynandowi).

3. Biblioteka Załuskich, (ręką J.A. Zaluskiego: „A-B").

A. Kawecka-Gryczowa, poz. 944.

149 Venero y Leyva Nenerus et (de) Leyva) Hieronymus, Examen episcoporum. Venetiis, apud Bertanus, $1645,2^{\circ}$

Stockholm KB

Oprawa: Pergamin biały. Na przedniej okładce wytloczony superekslibris Karola Ferdynanda z orderem Zlotego Runa i inicjałami: "C.F.P.P.".

Heymowski, s. 152, 159 poz. 18.

150 Vigerius Marcus (Emanuel), Decachordum Christianum Julio II Pont. Max. dicatum ... Hagenau, in aed. Th. Andhelmi ac lo. Alberti imp. lo. Koberger, 1517, $2^{\circ}$

Uppsala UB Teol. Asket. (30-259).

Prow.: 1. Biblioteka Zygmunta Augusta.

2. „Ex lib. serenis. Principis" (Zygmunta III).

A.Kawecka-Gryczowa, poz. 518.

151 Warszewicki Krzysztof, Caesarum, regum, et principum, unis et eiusdem partim generis et nominis ... Cracoviae, in officina Jacobi Siebeneycher, $1603,2^{\circ}$

Estr. 32, 215.

Uppsala UB

Oprawa: Aksamit czerwony. Pośrodku superekslibris z herbami Polski, Litwy, Szwecji i Gotlandii. W polu sercowym herb Wazów.

Heymowski, s. 151, 159; O.Walde II, 89.

$152^{*}$ Warszewicki Krzysztof, De cognitione sui ipsius libritres. Cracoviae, in officina lacobi Siebeneycher, $1600,4^{\circ}$

Estr. 32, 216-217.

BN XVI.F.426.

Oprawa: Skóra kremowa, tloczona w ozdobne ornamenty. Na przedniej okladce Orzeł w koronie, w polu sercowym herb Wazów. Pod herbem w obramowaniu wytłoczono: „IHS" z krzyżem.

Prow.: 1. „Dar H. Bukowskiego".

2. pieczęć: „Muzeum Narodowe w Rapperswyl”, na wewn. okladce ekslibris: „Biblioteka raperswilskan. 
153 Wolf Samuel, Stephani Primi serenissimi Poloniae regis ... Dantisci, typ. Jacobi Rhodi, 1582 (1583), $4^{\circ}$

Estr. 33, 267.

Västerås Stadsbiblioteket

Prow.: 1. "Ex libr. N. Niewiescinski A. 1589".

2. "Dan. Casim. Krusii”.

3. „Ser. Principis Caroli Ferdinandi”.

154 Wujek Jakub, Postilla Catholica mnieysza... Kraków, druk. Andrz. Piotrkowczyka, 1590, $2^{\circ}$

Estr. 33, 396.

Stockholm KB

Oprawa: Skóra biala, tloczona złotem w ozdobny wzór roślinny. Na przedniej okładce Orzeł w koronie, w polu sercowym herb Wazów. (Zygmunta III).

Prow.: 1. „Sten Bielke".

Sigismund Vasa, s. 106 poz. 164; Heymowski, s. 150, 159, poz. 8; Lindberg, s. 118, poz. 13.

\title{
WYKAZ EGZEMPLARZY W BIBLIOTEKACH
}

(liczby odsyłają do numerów spisu)

\section{a. biblioteki polskie}

\author{
BGdańska Biblioteka Gdańska PAN - 7, 110 \\ BJ Biblioteka Biblioteka Jagiellońska Kraków $-36,68,69,120$ \\ BKórnicka Biblioteka Kórnicka PAN - 52, 54, 146
}

BN Biblioteka Narodowa Warszawa $-9,14,20,27,29,43,74,91,92,93$, $94,97,101,115,118,152$

BUW Biblioteka Uniwersytecka Warszawa-10, 30, 38, 70, 87, 89, 114, 122 , $124,144,148$

BCzart. Muzeum Narodowe, Zbiory Czartoryskich Kraków-26, 106, 128, 136, 137

Bibl.Łopacińskiego Wojewódzka Biblioteka Publiczna im. H. Łopacińskiego - 87

Ossol. Biblioteka Zakładu Narodowego im. Ossolińskich Wroclaw $-64,78$

BSem. Duch. Biblioteka Seminarium Duchownego Lublin - 13

Wawel Państwowe Zbiory Sztuki na Wawelu Kraków - 143

Klasztor SS Wizytek Warszawa - 45

Biblioteka Kapitulna w Łowiczu - 95

Zamek Królewski w Warszawie - 81 


\title{
b. biblioteki zagraniczne
}

\author{
Berlin Staatsbk Deutsche Staatsbibliothek - 15 \\ Linköping Stifts-och Landsbiblioteket - 104 \\ Lund BU
Universitetsbibliotek $-1,2,3,6,11,12,16,18,19,22,23,24,25,33$, $34,35,37,41,44,46,47,48,49,51,57,58,59,60,61,62,63,66,71$, $72,76,79,80,83,86,90,98,99,100,102,105,109,112,113,116$, $121,123,125,127,129,130,132,135,138,142,145$

Östersund Jamlands läns bibliotek - 103

Skokloster

Skoklosters slottsbibliotek $-28,96$

Stockholm KB

Kungelike Bibliotek $-29,56,65,82,126,149,154$

Uppsala UB

Universitets Bibliotek $-4,17,21,31,39,40,53,55,73,84,85,107$, $108,117,119,131,133,134,139,140,141,149,150,151$

Västerås

Stadsbiblioteket $-5,8,32,50,77,88,111,153$

Wilno

Valstybinio V. Kapsuko Universiteto Moskoline Biblioteka - 42, 67, 75

\section{WYKAZ SKRÓTÓW BIBLIOGRAFII I DZIEŁ CYTOWANYCH}

Benzig

BMC

Brunet

Collijn

Estr.

Graesse

Hartleb

Heymowski
J. Benzig, Bibliographie Haguenoviensis. Bibliographie des ouvrages imprimés a Hagenau (Bas-Rhin) au XVle siecle, Baden-Baden 1973. Bibliotheca Aureliana I.

British Museum. General Catalogue of printed books ... to 1955, Vol. 1-263, London 1963-1966.

J.Ch. Brunet, Manuel du libraire et l'amateur de livres, T. 1-6, 5 ed. Paris (1928).

I. Collijn, Bericht über polnische Büchersammlungen in schwedischen Bibliotheken, "Bulletin de l'Academie des Sciences de Cracovie", 1911, s. 39-63.

K. Estreicher, Bibliografia polska, Cz. 3, T. 12-34. Kraków 1891-1951.

J.G.T. Graesse, Trésor de livres rares et precieux ou nouveau dictionnaire bibliographique, T, 1-7, Dresden 1859-1869.

K. Hartleb, Biblioteka Zygmunta Augusta, Lwów 1928.

A. Heymowski, Reliures armoriées polonaises de l'epoque des Jagellon et des Vasa dans les callection Suedoises, W: VIlle Congréss 
IAur

A.Kawecka-Gryczowa

S.Komornicki

Laucevičius

Lindberg

Z. Nowak

Panzer

Short Catalogue

Sigismund Vasa

M.Sipayło

Sprawozdania

Sztuka dworu Wazów

O.Walde
International des Bibliophiles. Varsovie... 1973, Varsovie 1985, s. 149-162.

Index Aureliensis. Catalogus librorum saedecimo saeculo impressorum, Aureliae Aquensis 1965-.

A. Kawecka-Gryczowa, Biblioteka ostatniego Jagiellona. Wroclaw 1988.

S. Komornicki, Zabytkowe oprawy średniowieczne, "Exlibris", R.7:1925, s. 22-23.

E. Laucevičus, XV-XVIIIa. knygu iriśimai Lietuvos bibliotekose, Vilnius 1976.

S.G. Lindberg, Reliures polonaises dans les bibliotheques suédoises de lage Gothique, de la Renaissance et de la Réforme, W: VIlle Congréss International des Bibliophiles. Varsovie... 1973, Varsovie 1985 , s. $70-121$.

Z. Nowak, Gdańskie ślady księgozbiorów znakomitych bibliofilów polskich doby Odrodzenia, "Roczniki biblioteczne", R.27:1983, s. 23-46.

G.W. Panzer, Annales Typographici, Vol, 1-11. Norimbergae 17931803. Reprint Hildesheim 1963-1964.

Short-title Catalogue of books printed in German, speaking countries and German books printed in over countries from 1455 to 1600 , London 1962.

Sigismund Vasa och hans sōner, Lidköping 1976.

M. Sipaylto, Polskie superekslibrisy XVI-XVII wieku w zbiorach Biblioteki Uniwersyteckiej w Warszawie, Warszawa 1988.

E. Barwiński, L. Birkenmajer, J. Łoś, Sprawozdania z poszukiwań $w$ Szwecji dokonanych z ramienia Akademii Umiejętności, Kraków 1914.

Sztuka dworu Wazów w Polsce. Wystawa w Zamku Królewskim na Wawelu maj czerwiec 1976. Katalog. (Kraków 1976).

O. Walde, Storhetstindes litterära krigsbyten. En kulturhistorisk-bibliografisk studie, T. 2, Uppsala 1920. 


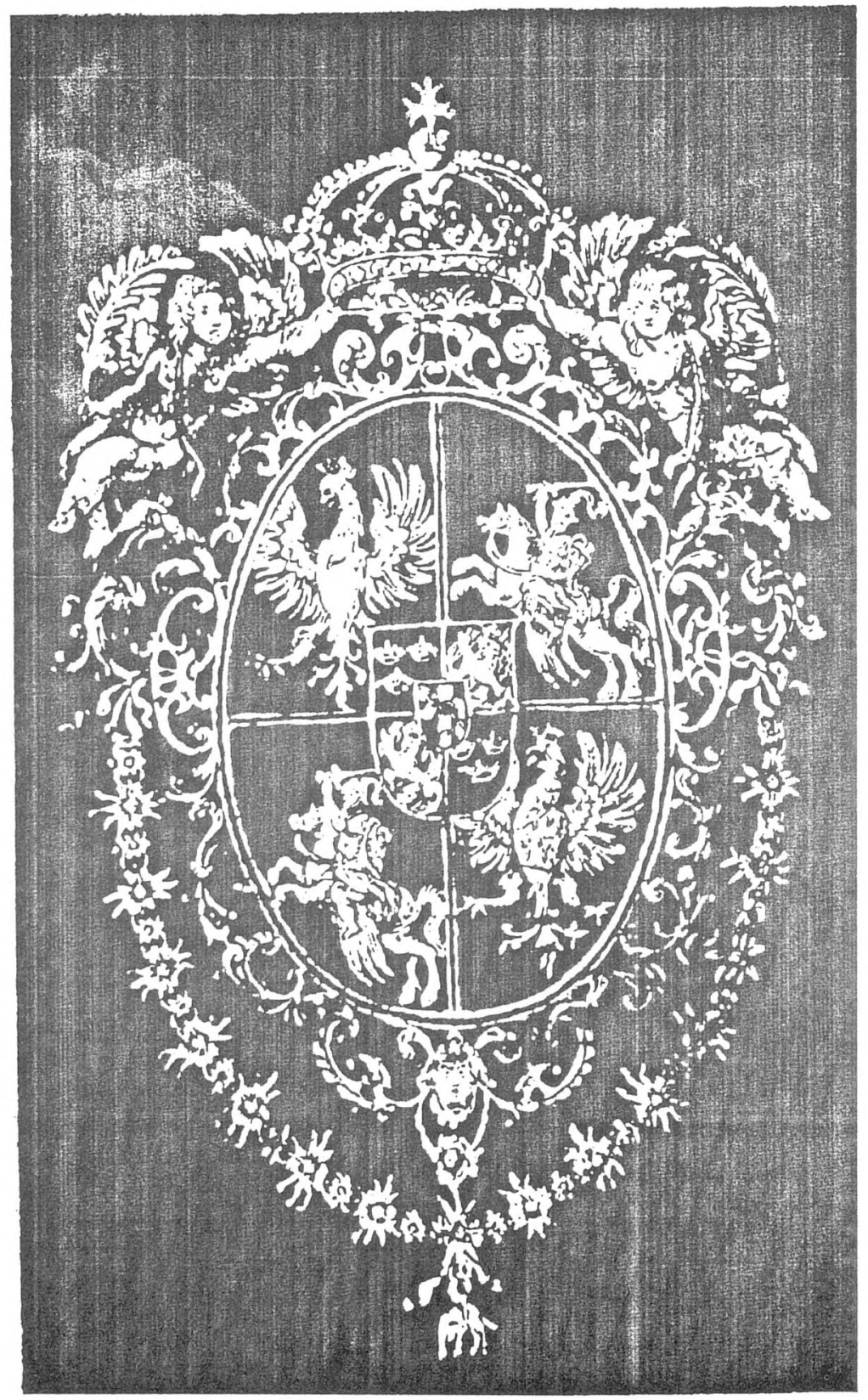

1. Superekslibris Zygmunta III (nr spisu 144) 


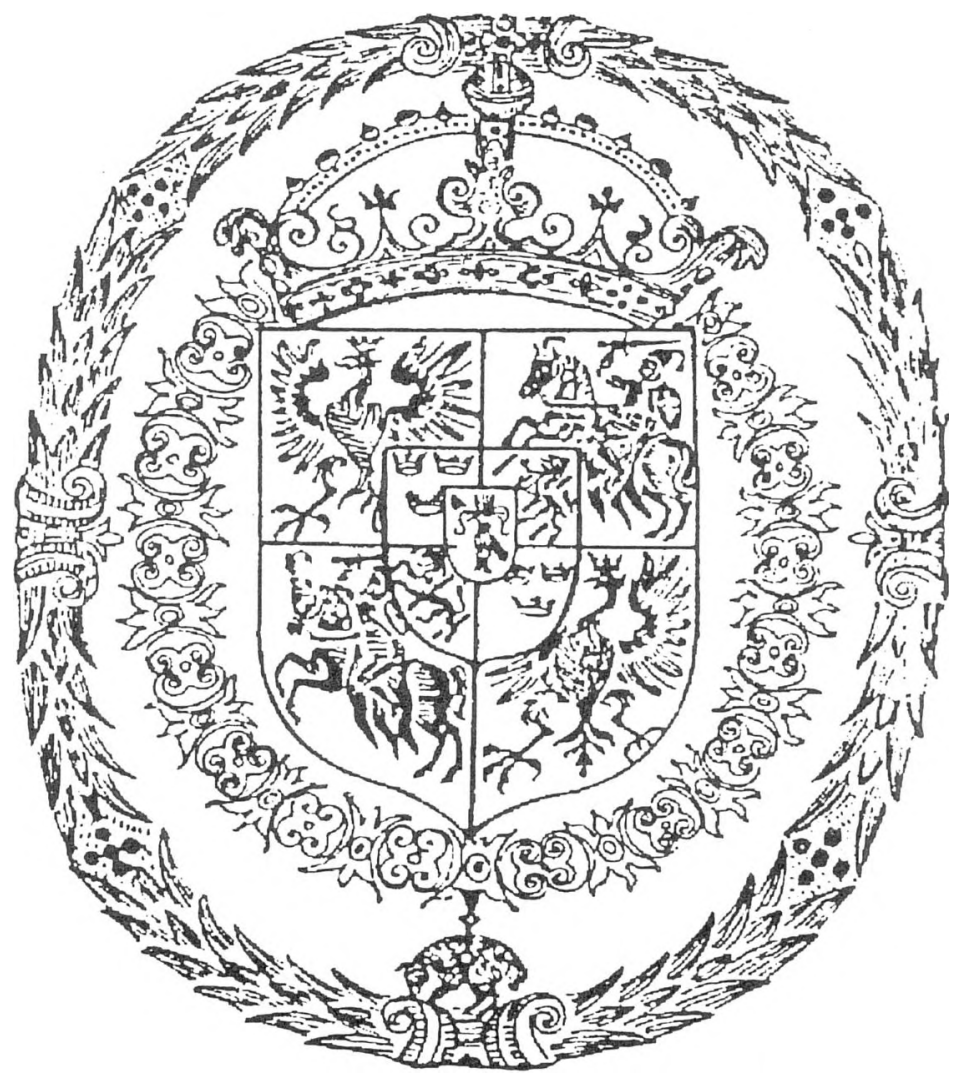

2. Superekslibris Zygmunta III, najczęściej spotykany na oprawach pergaminowych (nr spisu 23) 


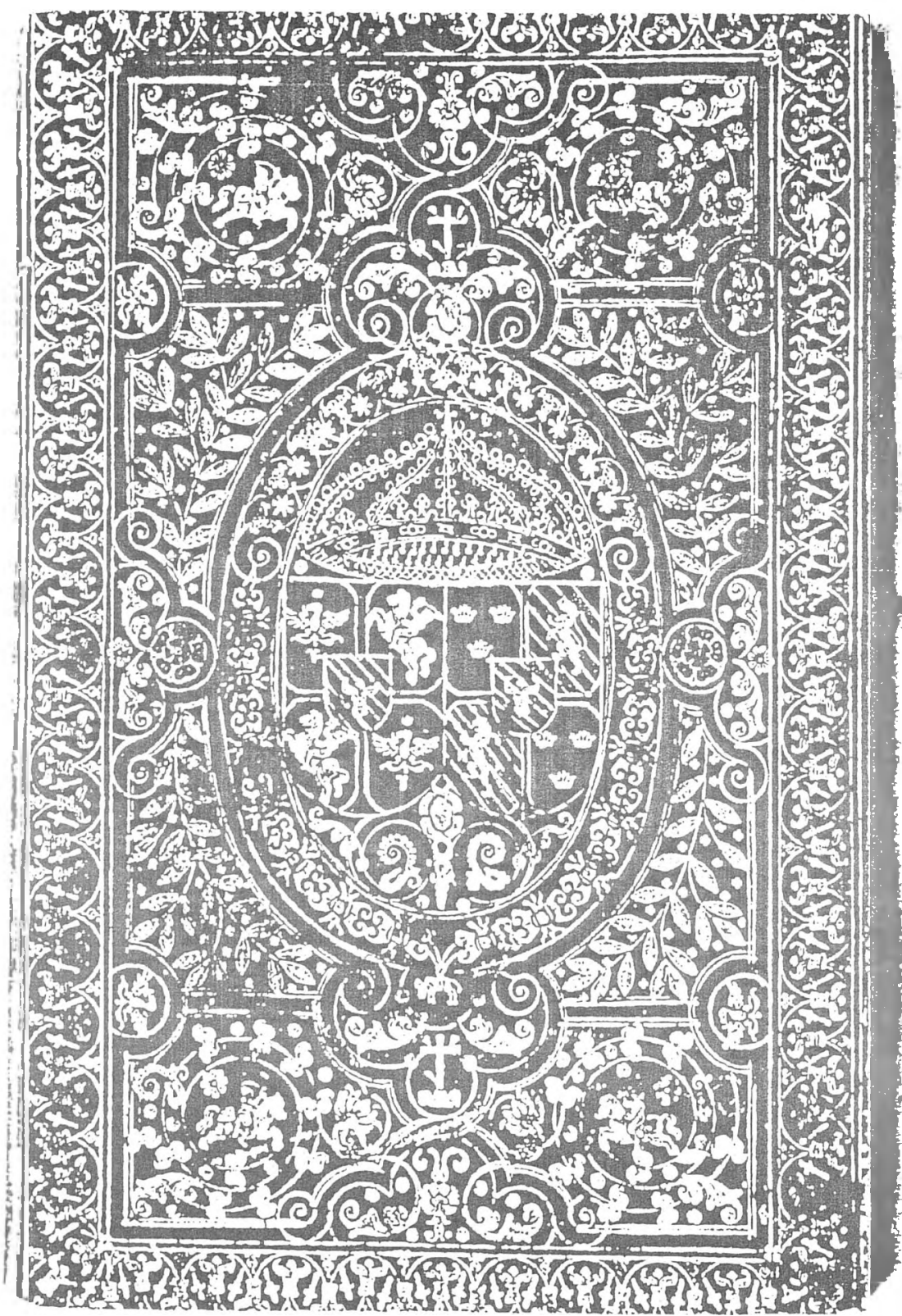

3. Oprawa donacyjna Zygmunta III. Okładka przednia (nr spisu 28) 


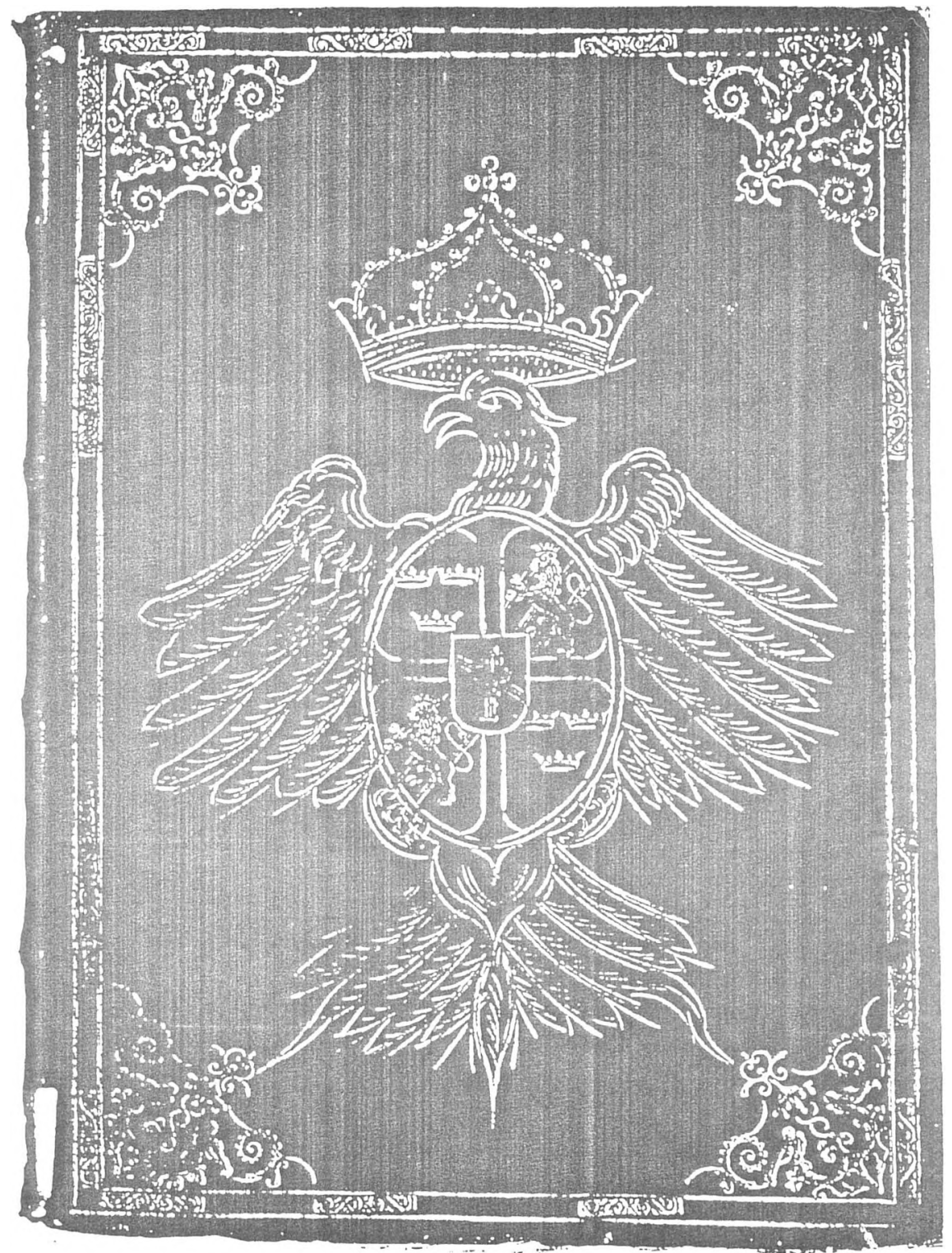

4. Oprawa książki Władysława IV. Okładka przednia (nr spisu 104) 


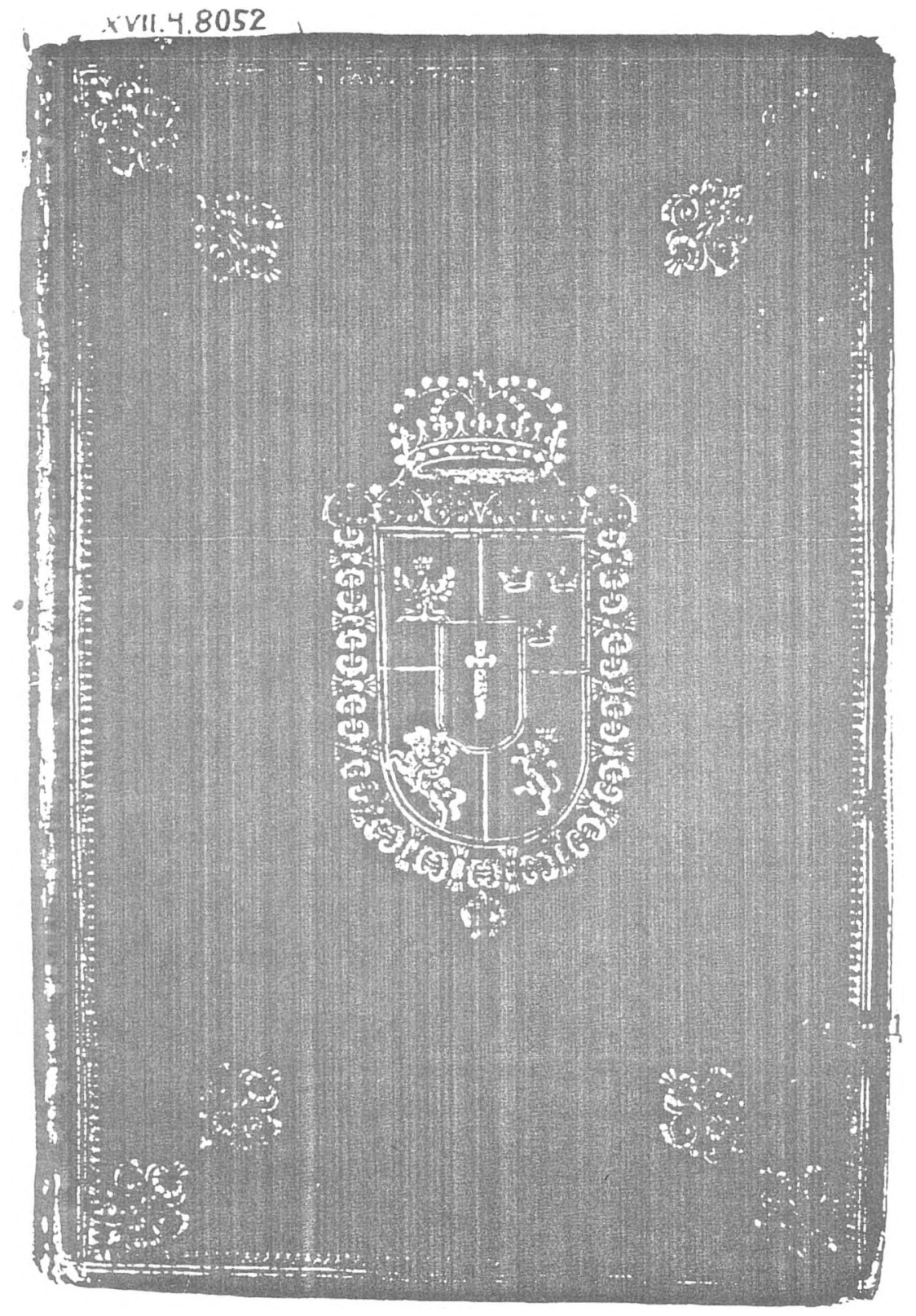

5. Oprawa książki Władysława IV. Okładka przednia (nr spisu 74) 


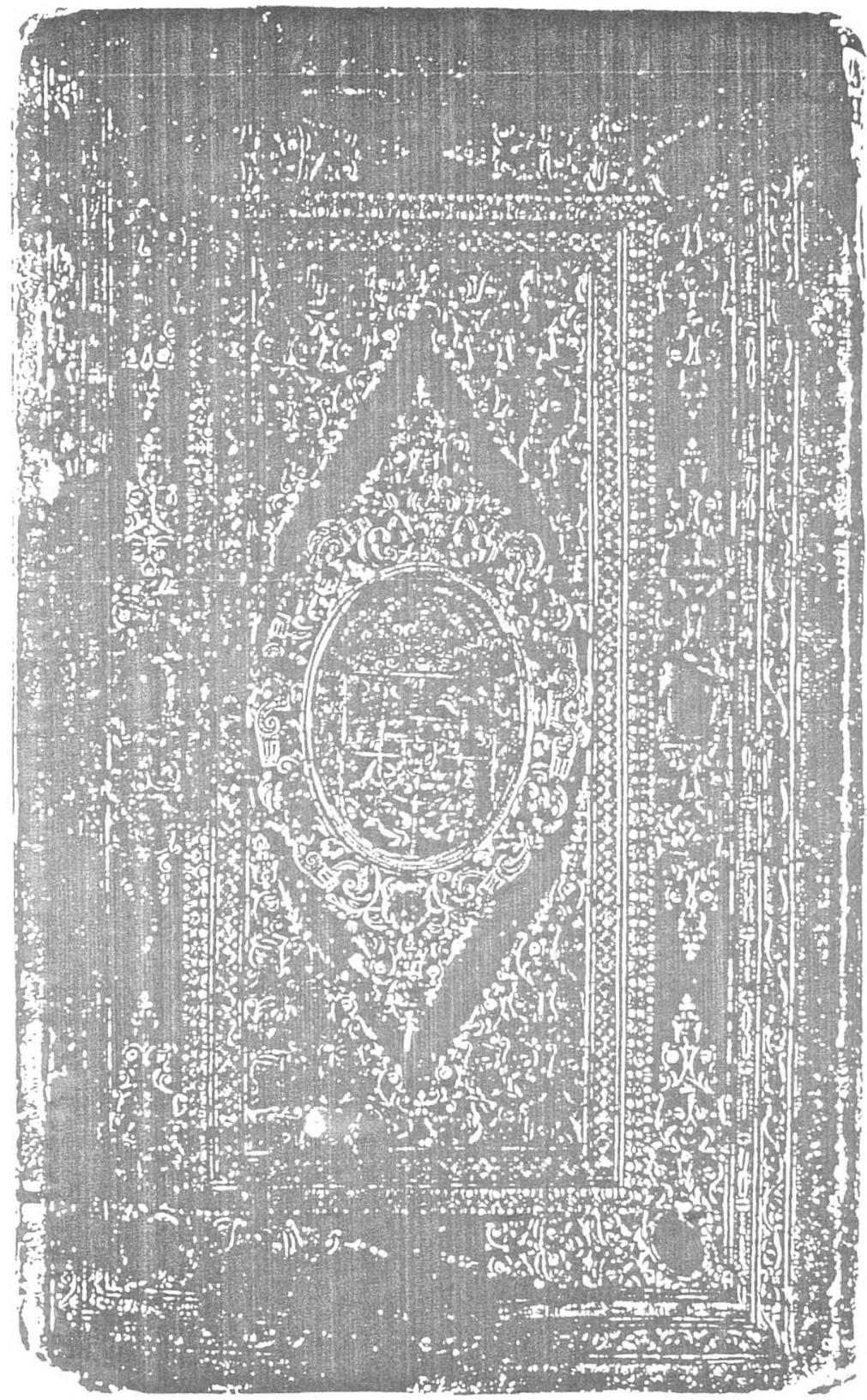

6. Oprawa książki Władysława IV. Okładka tylna (nr spisu 97) 


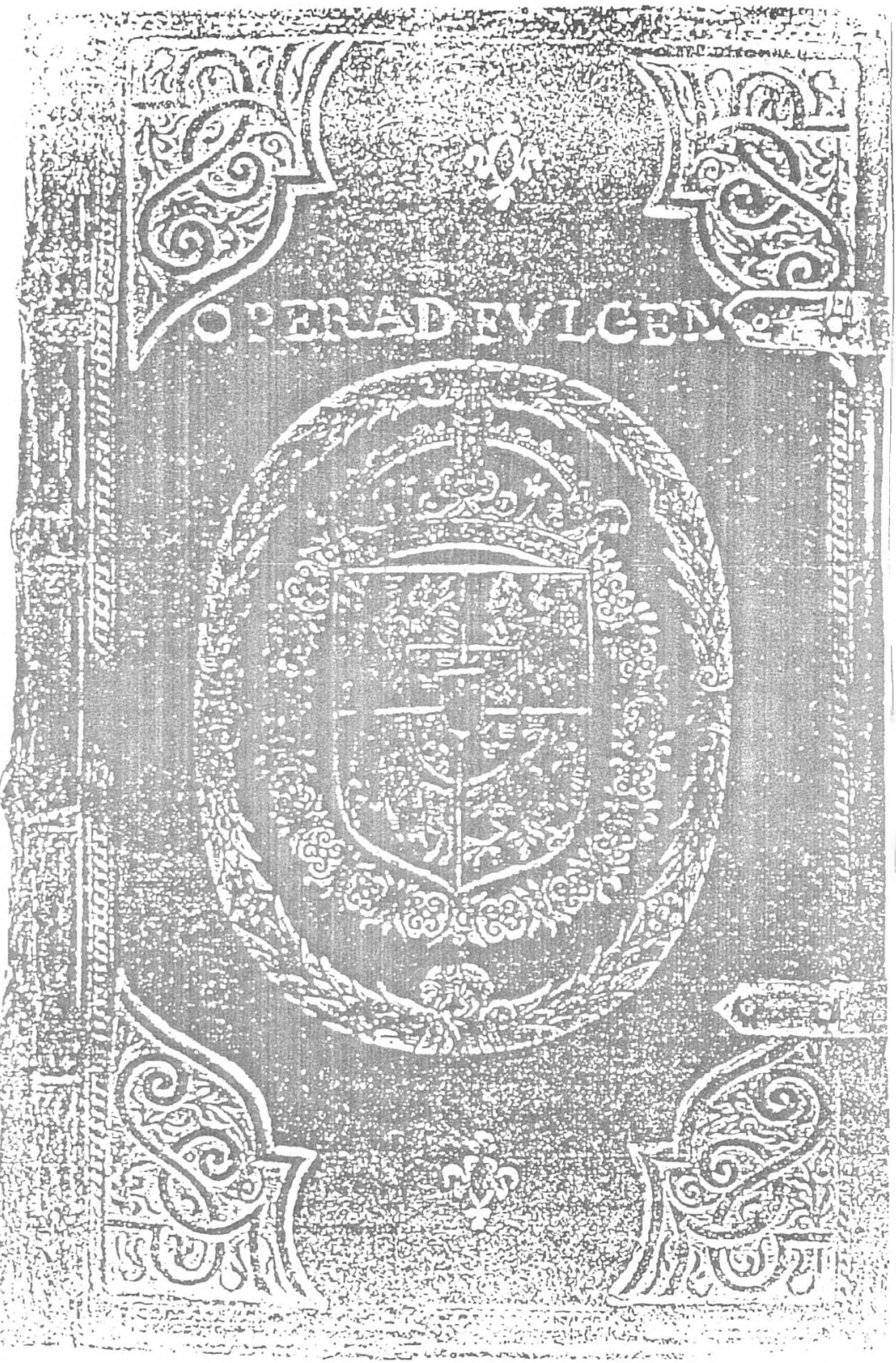

7. Oprawa książki Jana Kazimierza. Okładka przednia (nr spisu 67) 


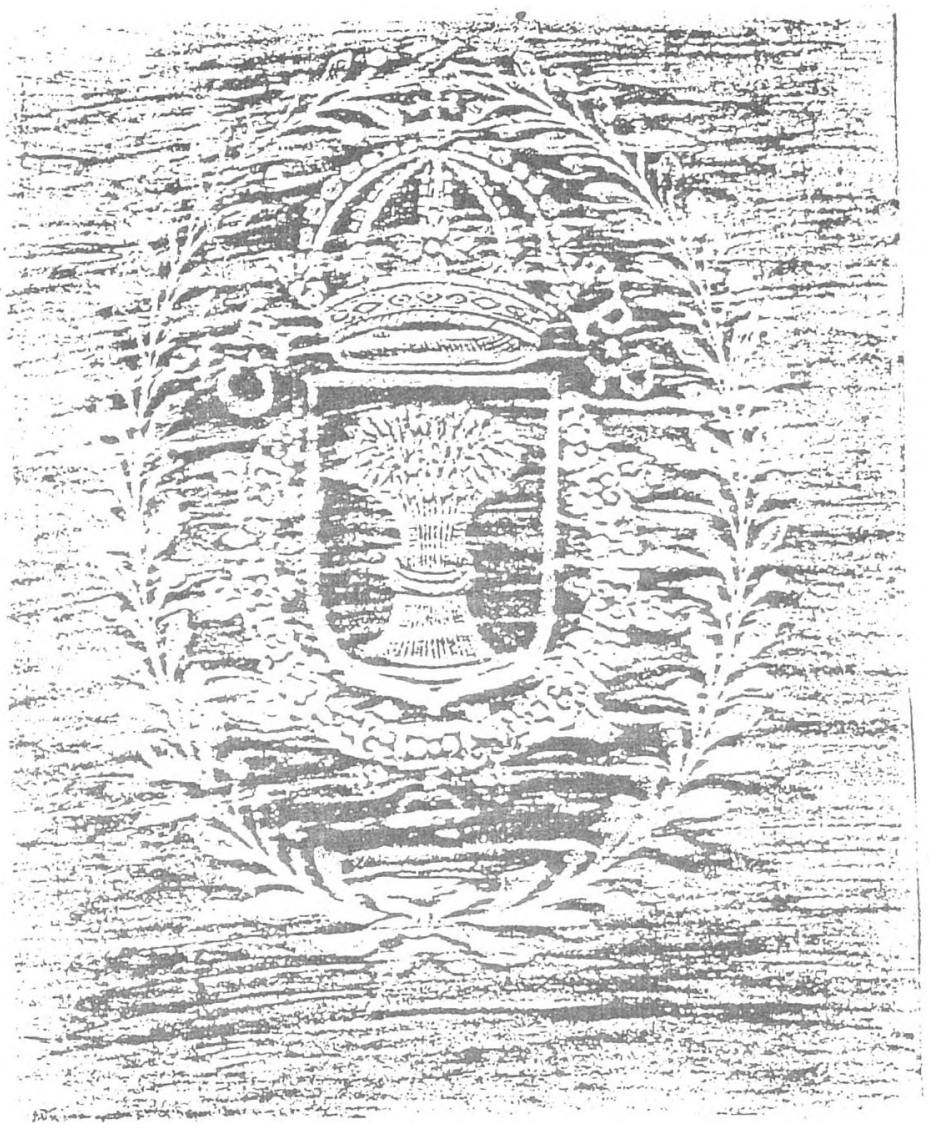

8. Superekslibris Karola Ferdynanda (nr spisu 43) 